\title{
MONOGRAPHIA \\ SOBRE O \\ CONVENIO FINANCEIRO DO BRAZIL
}

(The Funding Loan)

«O Frunding domina hoje, por todos os lados, a politica brazileira. Finanças, economia, administração, direito, politica, revisão, tudo vae topar nelle.»

RUY BARBOSA.

(Edit. da Imprensa de 30-6-99).

I-Antecedentes Fistoricos.-Synthese politica, economica e financeira.Soluções indicadas.-Alvitre preferido.-Casos de intervenção.

II-Theor do convenio.-Apreciações contrarias e favoraveis.-Dados estatisticos.-Confronto com o convenio argentino.

III-Execução do convenio.-Effeitos apreciados.-Inefficacia da incineração do papel.-Questão de principios...-Tentativas de resgate frustradas.

IV-Consequencias provaveis.-1)s pagamentos em especie.-Novação do contracto e unificação da divida externa.-Reformas tributaria e monetaria. -Opiniões diversas.

v-Conclusões.

\section{ANTECEDENTES HISTORICOS}

1). - Nenhum estudo imparcial e proveitoso sobre o convenio brazileiro de i 898 póde ser feito sem ter-se em linha de conta a excepcional gravidade, naquelle anno, da situação geral do paiz, tanto sobre o ponto de vista financeiro, como economico e politico. 
A não indicação, sob esse triplice aspecto, dos mais notaveis factos que exerceram influencia ou que determinaram aquelle acontecimento-além de attestar imperdoavel lacuna, impossibilitar-nos-ia de formar juizo completo e seguro sobre tão interessante assumpto.

- Por isso, ao começar este ligeiro escripto diremos que, sob o ponto de vista politico, o paiz se encontrava em um periodo de duvidas e incertezas, em uma época de transição de um governo que contava seus dias, após acirradas contendas, e de uma proxima administração que a todos acenava com as mais sorridentes esperanças.

Extinguia-se, pois, o primeiro quatriennio de um governo civil já bem fatigado com porfiada lucta, terriveis provações e custosa experiencia.

As questões externas da Trindade e das Goyanas; as reclamações italianas; as questões internas da guerra no sul e nos sertões da Bahia; o interregno da interinidade governamental; (I) o levante da escola militar; á scizão republicana de 3 de Junho de 1897; $\mathrm{o}$ attentado de 5 de Novembro do mesmo anno; o fechamento do Club Militar; a intolerancia partidaria; tudo em conjuncto, collocando, em crise permanente o governo, tornava-o menos forte para agir desembaraçadamente na resolução dos negocios financeiros já bastante complicados por uma série bem antiga de accumulados erros (2).

-Por sua vez a situação economica não offerecia base lisonjeira ás finanças do paiz, tal era, como infe-

(I) O Governo do então vice-presidente foi de II de Novembro de 1896 a 5 de Março do 1897 .

(2) Relativamente ao anno de 1897 assim exprimiu-se em seu relatorio o dr. Bernardino de Campos, ministro da Fazenda, pag. 15: "Os graves acontecimentos de. Março de 1897 , as perturbações de Maio, a campanha de Canudos e os crimes hediondos de 5 de Novembro marcam terriveis depressões na escala das relações commerciaes e financeiras.» 
lizmente ainda $\epsilon$, a baixa continuada e persistente do valor do nosso principal artigo de exportação, motivada pelo excesso de producção (I).

De facto, no periodo de I 895 a I 896 , seis milhões de saccas de café, cotadas na base de quatro libras cada uma, produziram vinte quatro milhões de libras; no de I 896 a I 897 oito milhões e quinhentas mil, cotadas a duas e meia libras cada uma, produziram vinte e uma mil duzentas e cincoenta libras; no de 1897 a 1898 onze milhões cotadas a uma e meia libra cada uma, produziram dezesseis milhões e quinhentas mil libras, sendo que aquelle vil preço, ainda hoje mal sustentado, reduzio á quasi metade o valor total da nossa exportação! (2)

Tão rapida quão colossal depreciação, occasionando enorme desequilibrio no balanço internacional $\mathrm{e}$ influindo directamente no mercado monetario, tornando onerosa a compra de lettras para os pagamentos no exterior, (3) não podia deixar de perturbar toda e qualquer combinação e permittir, ao mesmo tempo, as mais terriveis conjecturas!

A «crise havia chegado ao seu maior auge», como ainda ha pouco confirmou, em sessão de 26 de Junho ultimo, na Camara, o deputado Augusto Montenegro.

(I) O valor official da exportação do Brazil é mais ou menos de setecentos e cincoenta mil contos; o café figura na razão de quinhentos mil, a borracha na de cento e cincoenta mil e os outros productos na de cem mil.

(2) Vide a estatistica apresentada no parecer da actual commissão do orçamento (1899) e publicada na Gazeta Commercial e Financeira, de 9 de Setembro de 1899 .

(3) Nos referimos ao balanfo internacional, nestes tempos tão confundido com a balanca commercial. Esta indica a parte mais consideravel das transacções internacionaes, mas sómente aquellas que são constatadas pelas repartições aduaneiras; aquelle abrange o todo das transaç̧ões commerciaes e financeiras entre uma nação e todas outras com as quaes mantém relações commerciaes e financeiras.

E', porém, commum o erro de traduzir-se o termo bilan por balança e d'ahi, não raro, a proposital confusão. 
- A despeito de uma administração séria e honesta, sinistro aspecto offerecia a situação financeira do paiz.

No exterior o $4 \%$ brazileiro era cotado entre 42 e $44 \%$ e o $5 \%$ entre 47 e 49 isso nas vesperas do convenio. Semelhante depreciação jámais attingida pelos nossos titulos era o resultado de uma longa campanha de descredito promovida contra o nosso paiz,' por meio de falsas informaçoes telegraphicas adrede forjadas, como por exemplo a do celebre despacho de io de Outubro de 1896 do Times, annunciando, em um só dia, trezentas fallencias na praça do Rio!

No interior desde as caixas economicas que ainda sobrelevavam crescente retiradas ate a menos importante repartição aduaneira, onde as rendas publicas diminuiam consideravelmente, tudo afigurava-se um occeano de difficil trato.

Os emprestimos internos e externos contrahidos até então pelo governo civil (I) e que attingiram a mais de quatrocentos mil contos em papel, bastaram apenas para pôr em ordem os compromissos nacionaes, estando, em Junho de I 898, inteiramente exgottados os recursos para o governo attender a todas as exigencias da administração financeira.

A inquietação pela sorte das finanças brazileiras era geral em todos os espiritos patriotas. Os alvitres immediatamente aconselhados, taes como o monopolio do cafe, o arrendamento da estrada de ferro Central, o imposto pessoal, a severa fiscalisação nas rendas, de par com innumeras providencias administrativas e fiscaes, eram insufficientes para regular uma gestão finan-

(I) Os emprestimos internos contrahidos foram os seguintes: em I 895 de cem mil contos, juros $5 \%$ typo 95 ; em 1897 de sessenta mil contos; e os externos os seguintes: em I 894 de dois milhões de libras em lettras de 9, I2 e 15 mezes, typo 97 e em 1895 de seis milhões de libras ao typo de 85 , juros $5 \%$. 
ceira que, em I 895, verificava um deficit de 37.000 contos em I 896, outro de 40.000, em I 897, ainda outro de I 56.000 (!) todos elles principalmente occasionados pelo cambio cuja depressão, em junho de I 898, attingio a $57 / 8$ d. sobre Londres.

Tudo o que se pedia ao imposto, tudo que se arrancava ao bem-estar do povo, tudo o que se deixava de applicar a elementos do progresso, á explorações naturaes, tudo o que se deixava de dedicar a melhoramentos de qualquer ordem, era cada vez mais insufficiente para saciar esse abutre que nos devorava.

Historiando esta difficil phase porque passou o nosso paiz, eis como exprimiu-se o festejado publicista brazileiro dr. José Carlos Rodrigues:

«Parecia insolvavel a crise, que de longe vinha, perturbando toda vida economica e financeira da Republica. O rumor de que era inevitavel a bancarrota, murmurado com sinceridade por uns, pela ignorancia do estado real das cousas por muitos e por exploração de caracter partidario por alguns, não concorria pouco para o desalento que leva direito ao completo desanimo. Em conferencias publicas dizia-se com solemnidade, os remedios geralmente indicados para resolver as nossas difficuldades, já viriam tarde, o desastre era inevitavel. $\mathrm{Na}$ tribuna ouviam-se manifestações no mesmo sentido: A crise chegou, na verdade, ao ultimo periodo e percebia-se, claramente, no começo do anno de (1 898$)$ que era preciso a todo custo resolvel-a.» (2)

Tal era, em synthese, a situação em que se fez o accordo do funding.

(I) Edit. da Gazeta de Noticias de 22 de Junho de 1899.

(2) Vide o Jornal do Commercio de 19 de Novembro de 1898 onde se encontra um estudo completo e minucioso sobre a administração do expresidente da Republica, dr. Prudente de Moraes. 
2).-As soluções INDICADAS pelas circumstancias eram:- decretar bancarrota, um accordo para obter-se a reducção dos juros ou o recebimento destes por meio de emissão de novos titulos, espaçada a amortisação.

A suspensão dos pagamentos foi aconselhada na camara dos deputados e defendida por alguns organs de publicidade, especialmente o "Estado de S. Paulo» que, em uma série de artigos, procurava demonstrar a conveniencia desse decisivo alvitre que importava na recusa de todo e qualquer arranjo com o credor europeu.

Eis como argumentava aquella folha: (I) «Dado o actual preço do ouro é claro que antes de tudo torna-se preciso que a União effectúe com os credores um accordo pelo qual, por exemplo, durante cinco annos, deixe de pagar os encargos da divida que tinha com a condição de ser garantida-de nos dez annos subsequentes pagar conjunctamente, juros, juros atrazados e accumulados nesses cínco primeiros annos. Em cinco annos poderiamos reorganisar integralmente $o$ nosso systema economico e financeiro, apparelhar a nação por meio de leis e de riquezas reaes, para solver todos os seus compromissos.

Se a situação actual é, como se diz geralmente, tal que é forçoso chegarmos á insolvabilidade, $o$ dever do governo é dizer francamente ao paiz a verdade e acceitar a responsabilidade da suspensâo de pagamentos com a qual salvaria a naşăo, com o sacrificio apenas de sua propria popularidade».

Posto que o estado de bancarrota ou fallencia real se imponha sempre pela fatalidade dos aconteci-

(I) O Estado de $S$. Paulo, editorial de $2 \mathrm{I}$ de Março de 1898 e seguintes, sob o titulo «A União e o Cambio», devidos á penna do jornalista José Barbosa. 
mentos, tanto aos individuos como ás nações, (I) o certo é que achava-se o nosso paiz ainda em condições de preferil-o ou não, e portanto podemos inquirir:

A Republica sentia-se forte para manter-se após a bancarrota tanto em relação a politica interna como externa?

Os credores assistiriam impassiveis a declaração da bancarrota sem que o menor protesto viesse perturbar a vida do nosso povo?

Quaes as consequencias de se proclamar a insolvabilidade de um paiz, considerado exclusivamente sob o ponto de vista economico, um dos mais ricos do mundo?

o futuro.

Não. Havia toda conveniencia de se appellar para

- Relativamente á reduç̧ão de juros força é convir que, importando em immediato prejuizo dos credores, talve $z$ não fosse facil conseguil-a, embora tirando-se proveito das difficuldades do momento.

Admittida a hypothese desse assentimento sem que exigencia alguma quanto a quaesquer garantias para a nova ordem de cousas, assim demonstrou, posteriormente, as consequencias dessa solução, o dr. Ferreira de Araujo: - O total circulante dos emprestimos é de $£ 37.697 .900$, exigindo um serviço annual de juros $£$ r.652.108. Os outros serviços incluidos no funding, importando em I.I I 5:892, temos ahi o total de $£$ 2.768.ooo. Imagine-se que o Governo obteria a reducção a 80 , a 75 , a $50 \%$ nessas responsabilidades; teriamos, na primeira hypothese, $£ 2.2$ I 4.400;

(I) A' bancarrota declarada no 2. ${ }^{\circ}$ quartel deste seculo pela Georgia, Luisiana, Minesota, Florida, Alabama, as duas Carolinas, o Arkansas, Mississipi, Tennessee e Virginia (Estados Unidos) succedeu 0 facto singular do repudio da divida contrahida-sem que... (n'aquelle tempo) os governos europeos déssem o menor passo em soccorro da fortuna europea, ali gravemente fraudada. 
na segunda $£ 2.076 .600$; na terceira $£$ I.384.000. A que cambio obteria o Governo essas sommas dado que os credores fossem tão condescendentes que acceitassem tal reducção sem mais nada? Deixando de entrar absolutamente no mercado para aquellas responsabilidades o cambio de $5 \%$ subio á taxa de 8 , salvos os effeitos da anticipação, descontados pela especulação. Que cambio teriamos nós se, embora obtida a reducção de juros, o Governo pezasse ainda no mercado, para obter aquelle ouro que periodicamente teria que remetter para o exterior? ( $\mathrm{I}$ )

Esta objecção nos parece tanto mais acertada quanto é certo que o Governo tinha que acudir egualmente ao serviço em ouro de alguns emprestimos internos, sem exclusão das amortisações.

Tal solução, effectivamente, pouco adiantaria e até podia ter mallogrado exito, attendendo-se que actualmente o agio de ouro é de 242,76 ou a depreciação do papel attinge a $70,83 \%$ !

Nem se diga que aproveita o exemplo dado em Portugal pelo decr. de I 3 de Junho de 1892 e lei de 20 de Maio de 1893 , de accordo com cujas disposições não se deu ao credor extrangeiro, pelos juros vencidos, mais do terço em ouro. As condições eram inteiramente differentes e não se tratava de toda divida externa portugueza. (2)

3).- Restava o ALVITRE PREFERIDo do pagamento em papel dos juros vencidos, isto é, em titulos emit-

(I) Editorial da Gazeta de Noticias de 25 de Junho de 1899.

(2) Consulte-se o Diario do Governo de Portugal, de 2 de Julho de I 898, e correspondencia d'aquelle paiz para o Jornal do Commercio de $2 \mathbf{I}$ de Abril de I898, e o Estado de S. Paulo de I do mesmo mez e anno.

Em relação a outro caso singular de reducção provisoria a $30 \%$ do serviço em ouro da divida grega pela lei de 22 de Dezembro de 1893 , consulta-se o Jornal do Commercio de 13 de Novembro de 1897 , de I4 de Março de 1898 e a Imprensa de 26 de Junho de 1899. 
tidos a limitado praso e o que, importando em adiamento, era todavia mais facil de se obter.

Esse alvitre, não prejudicando o opportuno recebimento em especie, teve por base a convicção de serem transitorias as difficuldades financeiras do paiz e jámais o reconhecimento de sua insolvabilidade.

Além disso, creando uma situação relativamente folgada para o Thezouro, veio o convenio proporcionar mais tempo ao governo, ao poder legislativo para tomarem providencias a bem da reorganisação do paiz.

Criticando o convenio dizem os seus contrarios que elle:-a) augmentou o capital devido ou a divida externa;-b) mudou a situação dos credores que de simples chirographarios passaram a privilegiados com hypotheca sobre todas as Alfandegas do Brazil; $-c$ ) que afinal pela lettra de uma de suas clausulas declarou expressamente a bancarrota.

Contestando todas estas asserções diremos:-Augmentou o capital devido por ser isso mais vantajoso e preferivel ao systema até então quasi sempre observado de se pagar juros e amortisāções com o producto liquido de emprestimos novamente realisados. Ahi estão todos os relatorios dos ministerios da fazenda para attestar o asserto. (I) $\mathrm{Na}$ hypothese actual entregam-se titulos ao par, como dinheiro de contado, deixando-se, de em grande parte, ainda mais augmentar o capital devido por meio da suspensão por treze annos das amortisações; pelo systema antigo o au-

(I) O actual ministro da Fazenda $d r . J$. Murtinho, á pag. XVIII do seu relatorio escreve:- «Não é mysterio para ninguem que antes de 1889 , uma parte mais ou menos importante de diversos emprestimos externos, foi destinada ao serviço dos juros vencidos e de dividas já existentes.

Este facto foi se accentuando cada vez mais, de sorte que os ultimos emprestimos externos do regimen republicano foram quasi completamente absorvidos no pagamento de juros de divida no exterior.

A unica differença entre esse facto e o que se dá no accordo de I5 de Junbo é que neste o emprestimo, para pagamento dos juros da divida externa e garantia de estrada de ferro durante tres annos, foi feito pelos mesmos 
gmento era de facto, attendida esta exigencia, além do prejuizo occasionado pela differença entre o typo da emissão e o valor nominal do emprestimo, assim como pelo juro contado desde a data da operação. Quanto ao facto de se dizer que de credores desgarantidos passaram elles a credores privilegiados com primeira hypotheca sobre todas as alfandegas do Brazil é preciso que se faça uma distincção entre os titulos do funding e do debito antigo. Para estes é inexacto ter-se dado em garantia a hypotheca alguma, a hypotheca das alfandegas só existe em relação ao funding, cujos titulos representarão a $6 .^{\mathrm{a}}$ ou $7 .^{\mathrm{a}}$ parte de toda divida externa.

Demais, quanto á garantia hypothecaria, convém lembrar-se do que escreveu, o sr. cons. Rodrigues Alves, quando ministro da fazenda. (I)

«Em I 829 o emprestimo externo que levantamos, com hypotheca da renda das alfandegas, foi obtido pela taxa de $5 \%$, typo de 52 . Em I 839 lançamos o emprestimo a 76 e juros $5 \%$ com hypotheca das rendas das alfandegas e especialmente da do Rio de faneiro,

. Ainda em 1843 o atrazo no pagamento das amortisações dos nossos emprestimos externos subia a $£$ I.883.030. Para resgate do emprestimo portuguez de I 825 tivemos de contrahir emprestimo externo em I 852, com hypotheca das rendas das alfandegas.

credores a quem era devido o pagamento desses juros, ao passo que em outras épocas os novos emprestimos foram tomados por pessoas diversas.

O facto financeiro essencial nesta questão é o pagamento de uma divida com os recursos obtidos por um novo emprestimo. Esse facto essencial existe entre nós, ha muitos annos; o facto accidental é ser o emprestimo feito pelos mesmos credores dos juros vencidos; isso é o que se deu de especial no accôrdo de Junho.

E' por isso, sr. Presidente, que ninguem poderá negar que o embryão desse accordo vem dos tempos do antigo regimen e que a Republica, longe de destruil-o em seus elementos essenciaes, o alimentou e desenvolveu, determinando a explosão da catastrophe financeira de que aquelle accôrdo é a expressão.»

(I) Relatorio de 1896, pag. 25. 
Em i 854 não se fez o resgate do emprestimo de I 824 , que venceu-se, por não se poder levantar novo emprestimo em consequencia da guerra do oriente segundo declarou o relatorio do ministro da fazenda de então, Marquez do Paraná».

Declaração expressa de bancarrota, a julgar pela redacção do art. I. $^{\circ}$ do contracto onde se diz, que «O Governo reconhecendo não poder pagar em dinheiro os juros de sua divida externa», tambem não, por se cogitar da especie ou modo do pagamento e por não ter havido interrupção no serviço dos juros. Com os titulos entregues e com pequeno desconto o credor immediatamente foi recebendo em ouro os juros devidos, podendo preferir ficar com os mesmos titulos emittidos a $5 \%$ juro quasi pelo dobro do que geralmente o capital vence na Europa. Se fosse real a insolvabilidade quem acceitaria ao par os titulos do funding?

Se não pretendemos elucidar o assumpto, tão diversa e injustamente apreciado, qual a vantagem pratica de discutir-se um facto consumado? (I)

4).-Casos de intervenção. O eminente estadista brazileiro sr. conselheiro Ruy Barbosa examinando o convenio em face da pressão extrangeira, depois de explanar completamente o assumpto, (2) chegou, entre outras, ás seguintes conclusões:

(I) A operação do convenio foi iniciada pelo snr. Tootal, director do "London and River Plate Bank», commissionado por um poderoso grupo de possuidores de titulos brazileiros; depois foi profundamente modificado em suas bases e acceito pelo dr. Bernardino de Campos e o Governo secundados em Londres pelo $d r$. Campos Salles, então presidente eleito da Republica. Vide o Jornal do Commercio de 12 de Julbo de 1898.

(2) Vide os editoriaes da Imprensa de 30 de Junbo, 1, 2, 4, 6 e 7 de Julbo do corrente anno, sob as seguintes epigraphes-O problema-Os direitos do devedor $-A$ theoria dos credores- $A$ attitude das potencias- $A$ independencia dos Estados-A solução. 
«Tres theorias disputam, na materia, a palma da verdade: a que impõe ao governo da patria do credor a obrigação de intervir (é a theoria dos credores); a que the nega a obrigação, mas the reconhece 0 direito (é a theoria dos estadistas e juristas britani$\cos )$; a que o absolve da obrigação recusando-lhe, ao mesmo tempo, o direito (é a opinião commum, sem chegar a ser o jus receptum, na doutrina).

Refugada por todas as auctoridades e inclusive a dos factos, a theoria da intervenção obrigatoria, que só no gremio suspeito dos interessados tem adeptos, fica circumscripto o debate ás duas ultinıas; a que admitte como diveito a intervenção e a que de todo o desconhece a não ser noos casos extremos de má fé, desigualdade em protecção de uns credores contra outros, ou abono do debito ao credor pelo interventor.

A theoria, que proclama em these esse direito, na pratica o desmente; porque nunca o exerceu contra as nações, fortes, apezar de serem por parte dessas, insignes os casos de attentado contra os direitos commerciaes dos seus credores. Ainda em relação aos Estados mal defendidos, ou indefesos os casos de uso desse arbitrio tem sido excepcionaes na historia internacional da bancarrota, e quasi todos alludem a povos situados na zona fronteira entre o oriente e o occidente, entre a civilisação christã e estados sociaes inferiores. ( $\mathbf{I}$ )

O que fica magistralmente escripto nos habilita a acreditar que em face da honrosa e tradicional conducta do Brazil em attender pontualmente os seus com-

(I) N'esta cathegoria estão o Egypto, a Turquia e Tunis. No primeiro interveio a Inglaterra em 1876 , i 882 e 1885 ; no segundo a mesma potencia e a França, em I855; no terceiro a França. 
promissos á obstinação ou á cegueira dos seus credores, nenhuma medida violenta podiam ou podem obter a seu favor dos governos europeus.

Essa convicção, porém, não basta para nos premunir contra situações que, por ventura, no futuro possa encontrar-se a nossa patria. E' manifesta a suprema necessidade do nosso governo e dos nossos legisladores cuidarem de a tempo amparal-a; é esse o brado unisono de todos os brazileiros!

\section{THEOR DO CONVENIO}

5).- Contracto feito a i 5 de Junho de 1898 entre o Governo da Republica do Brazil (daqui em diante denominado «O Governo» representado pelo bacharel José Antonio de Azevedo Castro, Delegado do Thesouro Brazileiro na Inglaterra, de un lado e os srs. N. M. Rothschild \& Sons de New-Court St. Swithins Lane in the City of London, na Inglaterra, banqueiros e negociantes (daqui em diante denominados «srs. Rothschild»), de outro lado, pelo qual o Governo, reconhecendo não poder pagar em dinheiro os juros dos emprestimos de sua divida externa, os do da Companhia Estrada de Ferro Oeste de Minas de 1893 de $5 \%$ garantido, os do emprestimo interno ouro de $4 \% \frac{1}{2}$ de 1879 e as sommas pagaveis ás diversas Companhias de estradas de ferro garantidas (uma lista desses emprestimos e das estradas de ferro garantidas foi inserida no annuncio, cuja cópia vai annexa) e tambem não poder prover o fundo de amortização dos diversos emprestimos e de resgate do de $4 \frac{1}{2} \%$ interno ouro de I879, resolveu, usando das autorisações dadas na lei permanente de I I de Setembro de I 846 , n. 40 I, confirmada pelas de 9 e ro de De- 
zembro de i 896; ns. 427 e 428 e*pela lei de Orçamento de 15 de Dezembro de I897, n. 489, fazer o accôrdo abaixo indicado relativo ao pagamento dos ditos juros e suspender a operação dos diversos fundos de amortização durante $o$ periodo infra-mencionado.

$\mathrm{E}$ como as letras do Thesouro referentes ás $£ 2.000 .000$ emittidas em Janeiro de 1898 devem ser especialmente excluidas do accôrdo assim feito e devidamente pagas de conformidade com o contracto, conforme o Governo por este declara, isto posto o Governo por este declara-que os juros dos diversos emprestimos e de sommas pagaveis pelas garantias devidas em I $^{\circ}$ de Janeiro de 1898 ou em qualquer data posterior até 30 de Junho de I 90 I não serão pagas em dirheiro, mas satisfeitas pela emissão de Titulos consolidados (Funding bonds) que deverão ser emittidos periodicamente, vencendo o juro annual de $5 \%$; e em relação aos ditos fundos de amortização e resgateque os mesmos serão suspensos até 30 de Junho de I9II. E em firmeza do que é por meio deste accordado e declarado pelas partes o seguintes:

I.-O Governo, por intermedio dos srs. Rothschild emittirá titulos, que serão denominados «United States of Brazil $5 \%$ Funding Bonds» em somma não excedente ao total de $£$ ro.000.00o, vencendo o juro de $5 \%$ ao anno.-Os ditos titulos serão garantidos por uma primeira hypotheca das rendas da Alfandega da Capital Federal do Rio de Janeiro (sujeitas apenas ao provimento do pagamento do capital e juro das ditas 2.000.000 libras esterlinas em letras do Thesouro) e comprehendendo tal hypotheca, como garantia accessoria, as rendas das Alfandegas de todos os outros portos dos Estados-Unidos do Brazil, no caso de serem insufficientes as da Alfandega da Capital Federal. 
2.-Durante o preparo dos titulos os srs. R̈othschild emittirão cedulas que serão depois trocadas pelos titulos. As cedulas ou titulos serão emittidos periodicamente pelos srs. Rothschild aos possuidores de coupons dos diversos emprestimos, cujo pagamento de juros em dinheiro é suspenso, como e quando esses coupons forem apresentados para pagamento, e tambem como e quando fôr requerido o pagamento das garantias dadas ás estradas de ferro. A emissão será feita á razão de $£$ I o० nominaes de titulos por $£$ I dos juros pelos quaes é o Governo directamente responsavel e das sommas pelas quaes é elle responsavel sob suas garantias. As cedulas ou titulos vencerão juros da data em que se vencerem os coupons ou garantias pelas quaes forem emittidas.

3.-Os titulos serão resgatados no periodo de 63 annos a partir de $1 .^{\circ}$ de Julho de 1898 , por meio de um fundo de amortização accumulado de: $1 / 2 \%$ ao anno, que deverá começar em I. de Julho de I9II e será applicadlo semestralmente em I. ${ }^{\circ}$ de Janeiro e I. de Julho de cada anno, na compra de titulos quando o preço estiver abaixo do par e em sorteios, realizados em Londres em presença de um notario publico, pela fórma do costume, quando o preço estiver ao par ou abaixo do par. Qualquer titulo sorteado - para pagamento será, juntamente com o juro que, de accôrdo com o theor do titulo, fôr por elle devido, pago no fim de um mez da data do sorteio. Os titulos sorteados deixarão de vencer juro da data em que se tornarem pagaveis. Os juros dos titulos serão representados por coupons annexos aos mesmos e serão pagaveis por trimestres em I.. de Janeiro, I..$^{\circ}$ de Abril, I. ${ }^{\circ}$ de Julho e I. $^{\circ}$ de Outubro de cada anno em Londres na casa bancaria dos srs. Rothschild em libras esterlinas e tambem em Paris, Amsterdan, Bruxellas e Hamburgo ao cambio do dia sobre Londres, devendo 
o primeiro pagamento de taes juros ser feito em $\mathbf{I} .^{\circ}$ de Outubro de I 898. Os srs. Rothschild receberão I $\%$ sobre a importancia dos coupons por elles pagos e $1 / 2 \%$ sobre a importancia nominal dos titulos resgatados com $1 / 8 \%$ addicional de corretagem sobre os titulos comprados, porcentagens estas que são as concedidas em relação aos emprestimos do Governo.

4.-Os titulos serão da fórma que fôr approvada pelos srs. Rothschild e trarão as assignaturas do representante do Governo Brazileiro e dos srs. Rothschild ou de seu representante e serão isentos de todos os impostos brazileiros presente, e futuros, quer ordinarios quer extraordinarios.

Os titulos ou qualquer outro titulo geral contemporaneo ou outro documento, conforme fôr necessario, hypothecarão completamente as rendas da Alfandéga da Capital Federal do Rio de Janeiro como principal garantia e as das Alfandegas dos outros portos dos Estados-Unidos do Brazil como garantia accessoria do serviço dos titulos. Todas as despezas de qualquer natureza relativas á execução do accôrdo assim estipulado, inclusive o custo da impressão das cedulas e titulos e o sello delles tanto na Inglaterra como no Exterior, serão por conta do Governo.

5.-Afim de attender ao pagamento dos juros das cedulas ou titulos e a amortização destas e outras despezas respectivas, o Governo, quinze dias pelo menos antes da data em que qualquer pagamento de juros deva ser feito ou qualquer compra ou sorteio tenha de ser effectuado, remetterá por sua conta e risco aos srs. Rothschild em Londres os fundos necessarios para os fins supra indicados.

6.--Os srs. Rothschild receberão como remunèração dos seus serviços prestados e dos que tenhão de ser prestados relativamente ao accôrdo á emissão 
dos titulos, uma somma igual a I $\%$ sobre a importancia nominal maxima dos titulos e mais, como remuneração ás casas estrangeiras por intermedio de cujas A'gencias os titulos sejam emittidos no exterior, $1 / 4 \%$ sobre a importancia nominal dos titulos emittidos por intermedio delles.

As ditas porcentagens serão pagas sobre a importancia nominal dos titulos quando forem periodicamente emittidos.

7.-A emissão dos titulos e a sua troca por coupons dos antigos emprestimos e a emissão dos titulos para as sommas pagaveis sob garantias, se fará nos termos do annuncio inserto nas principaes folhas diarias de Londres (cuja minuta foi approvada pelo dito Delegado) e uma cópia da qual é annexada a este contracto e que deverá ser considerado parte do mesmo e a elle incorporado da mesma maneira em todos os respeitos como se as clausulas contidas no dito annuncio fossem aqui repetidas.

8.- O Governo antes de.$^{\circ}$ de Julho de I90 I não emittirá emprestimo algum externo, não permittirá que emprestimo algum seja emittido sob sua garantia, nem emittirá emprestimo algum interno cujos juros devam ser pagos na Europa a cambio determinado sem prévio accôrdo escripto dos srs. Rothschild.

9.--O Governo terá liberdade de, em qualquer tẻmpo, resgatar ao par os titulos em circulação e a realização de qualquer nova operação que fôr desta arte julgada necessaria será confiada aos Srs. Rothschild.

I o.-O Governo communicará sem demora ao Congresso que o accôrdo com os possuidores de titulos e outros providos por este contracto foi effectuado.

Como testemunho as mãos das partes, no dia e anno primeiro acima escripto, assignaram pelo dito bacharel José Antonio de Azevedo Castro em presença de 
- pelos ditos srs. Rothschild \& Sons em presença de — «Funding Scheme» (I) dos Estados-Unidos do Brazil:

Tendo o Governo dos Estados-Unidos do Brazil resolvido consolidar (to fund) durante tres annos, isto é, de I. $^{\circ}$ de Julho de r 898 a 30 de Junho de I9or, os juros da Divida Externa, os do emprestimo interno ouro de $4 \frac{1}{2} \%$ de 1879 e tambem diversas sommas pagaveis annualmente pelas garantias de Estradas de Ferro, s. excia. o sr. Ministro da Fazenda, de accôrdo com as leis ns. 40I de II de Setembro de I 846 , 427 de 9 de Dezembro de 1896,428 de ro de Dezembro de 1896 e 489 de 15 de Dezembro de 1897 , auctorisou os srs. N. M. Rothschild and Sons a emittirem uma somma não excedente a $£$ r 0.000.000, capital nominal $5 \%$, em titulos especialmente garantidos pela renda das Alfandegas, como abaixo se declara.

Os seguintes emprestimos serão incluidos no plano:

Emprestimo de 1883

Emprestimo de 1888 .

Emprestimo de 1889

Emprestimo de I 895

Emprestimo garantido de $1893 \quad 5 \%$.

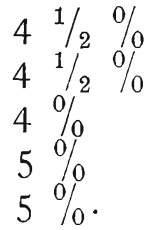

A Companhia Oeste de Minas

Emprestimo interno, ouro de. $4 \frac{1}{2} \%$ de 1879.

E tambem as sommas garantidas das seguintes Estradas de Ferro:

The Alagôas Railway Company (Linha Principal).

The Alagôas Railway Company (Ramal da Assembléa).

The Greath Western of Brazil Railway Company.

The Conde d'Eu Railway Company.

The Central Bahia Railway Company.

(I) Prospecto. 
The Brazil Greath Southern Railway Company.

The Bahia and São Francisco Railway Company '(Timbó Branco).

The Dona Thereza Christina Railway Company.

Southern Brazilian Rio Grande do Sul Railway Company.

Companhia Mogyana.

The Minas and Rio Railway Company.

The Natal and Nova Cruz Railway Company.

Compagnie Générale de Chemins de Fer Brésiliens (Paranaguá a Curityba).

Compagnie Générale de Chemins de Fer Brésiliens (Prolongamentos e Ramaes).

Compagnie de Chemins de Fer Sud Ouest Brésiliens (Linha de Santa Maria a Cruz Alta).

Compagnie des Chemins de Fer Sud Ouest Brésiliens (Linha de Cruz Alta a Uruguay).

The Bahia and São Francisco Railway Company.

The Recife and São Francisco Railway Company.

Chemins de Fer São Paulo and Rio Grande.

Os fundos de amortização e resgate dos emprestimos serão suspensos por espaço de treze annos a partir de I. $^{\circ}$ de Julho de 1898.

Os ditos titulos de $5 \%$ serão especialmente garantidos pela renda da Alfandega do Rio de Janeiro sobre a qual terá primeiro emprego (preferencia), depois de cleduzida a somma necessaria para o pagamento das $£ 2.000 .000$ em letras do Thesouro emittidas em Janeiro de 1898 que são reembolsaveis, á razão de $£ 500.000$ por semestre, sendo a primeira prestação devida em I. ${ }^{\circ}$ de Julho de i 898 . Os titulos serão garantidos pela renda das Alfandegas dos outros portos da União, no caso de ser em qualquer tempo insufficiente a da Alfandega do Rio de Janeiro. 
Segundo os relatorios officiaes a renda da Alfandega da Capital Federal elevou-se em r 897 a 92.000 contos de réis, equivalente ao cambio de 7 d. a $£$ 2.683 .333 e, ao cambio de 8 d., a $£ 3.066 .666$.

A renda total das Alfandegas da União, inclusive a renda acima indicada, elevou-se a 244.000 contos de réis, equivalente ao cambio de 7 d. a $£$ 7.I I 6.666 e ao de 8 d. a $£$ 8.133.333.

Em I. ${ }^{\circ}$ de Janeiro de 1899 e dessa data em diante, pari passu com a emissão dos Titulos, o Governo depositará no Rio de Janeiro em trust no London and River Plate Bank, Limited, London and Brasilian Bank, Limited e Brasilianische Bank für Deutschland, o equivalente dos ditos titulos em papelmoeda corrente ao cambio de 18 d. e o papel-moeda equivalente aos titulos emittidos de I. $^{\circ}$ de Julho a $3 \mathbf{I}$ de Dezembro de r 898 será depositado pela mesma fórma durante o periodo de tres annos a contar de I. de Janeiro de 1899.

O papel-moeda depositado ou será retirado da circulação e destruido, ou, se e quando o cambio tornar-se favoravel, será applicado na compra de lettras em Londres a favor dos srs. N. M. Rothschild \& Sons, afim de ser levado ao credito do «Fund» para o futuro pagamento em ouro dos juros dos emprestimos e garantias das Estradas de Ferro.

Os titulos de $5 \%$ serão isentos de todos os impostos brazileiros.

Os titulos serão ao portador do valor de $£ 2$, $£$ 100, £500, £ r.000 cada um, com coupons para juros á razão de $5 \%$ ao anno, pagaveis por trimestre a.$^{\circ}$ de Janeiro, I. $^{\circ}$ de Abril,.$^{\circ}$ de Julho e.$^{\circ}$ de Outubro, em Londres, em dinheiro esterlino e em. Paris, Amsterdam, Bruxellas e Hamburgo ao cambio do dia sobre Londres. 
Os titulos serão resgatados pelo fundo de amortização accumulado de $1 / 2 \%$ ao anno que será applicado semestralmente na compra de titulos quando o preço estiver abaixo do par, e, quando estiver ao par ou acima do par, por meio de sorteios, $O$ resgate dos titulos por meio do fundo de amortização começará no fim de dez annos contados de 30 de Junho de I 90 I, mas o Governo reserva-se o direito de pagar o emprestimo ao par em qualquer tempo.

Este plano foi fornuiado com approvação do dr. Campos Salles, Presidente eleito da Republica, que durante a sua recente visita a Londres esteve em communicação constante com o seu Governo sobre o assumpto; e antes de sua partida manifestou S. Ex. ${ }^{a}$ sua satisfação pelo plano e assegurou que durante sua administração fará quanto estiver em seu poder, afim de collocar em bases solidas as finanças do Brazil e restabelecer o credito de seu paiz.

- Condições que devem ser observadas pelos possuidores de titulos dos emprestimos supra mencionados, para a consolidação (funding) de seus coupons que deverão ser apresentados até 30 de Junho de I90 I, inclusive.

Em troca de seus coupons, receberão os possuidores um recibo da importancia depositada.

Esses recibos devem ser apresentados em importancias não inferiores a $£ 20$ para serem trocados por cedula, que será depois trocada por titulos do novo emprestimo de $5 \%$.

Sendo o menor valor do titulo $£ 20$, dar-se-hão certificados para as fracções de $£ 20$, e estes podem ser depois trocados por cedula ou titulo pela mesma fórma que os recibos, isto é, em importancia não inferiores a $£ 20$.

Nenhum juro será pago sobre os recibos ou certificados fraccionaes, mas a cedula ou titulos dados em 
troca dos recibos ou certificados vencerão juros da data vencida dos coupons para os quaes foram os recibos emittidos.

Os recibos e certificados para os coupons vencidos em differentes datas devem ser conservados em separado, quando apresentados para serem trocados por cedulas.

Sómente recibos e certificados para coupons vencidos na mesma data pódem serem pregados conjunctamente para perfazerem a somma para ser trocada por cedulas ou titulos.-New Court, E. C. I 5 Junho 1898.

6).-Apreciações contrarias ao convenio. O illustrado snr. conselheiro Ruy Barbosa não tardou muito em manifestar-se contra o convenio, criticando em uma série de artigos as suas principaes clausulas bem como a propria redacção onde se via a confissão official da nossa insolvencia. ( $\mathrm{I}$ )

Affirmando que a situação economica e financeira do paiz impunha o alvitre da novação de todos os contractos para se alterar equitativamente as condições da nossa responsabilidade, mediante juro menos oneroso e amortisação menos forte, condemnou francamente o convenio que, no seu modo de ver, não passa de uma aggravação da divida em troco de momentanea folga, para mais tarde o paiz ficar nos mesmos embaraços augmentados por um debito addicional.

Escreveu s. excia.:- «Funding loan, expressão que por tantos modos' se tem tirado em vulgar entre nós, quer dizer propriamente emprestimo de capitalisação. E' uma operação mercantil, que, dispensando temporariamente ao devedor o serviço de amortização e

(I) Vide a collecção da Imprensa relativa aos mezes de Junho e Julho de I 899 . 
juro, os vae successivamente accumulando ao capital primitivo, e augmentando assim progressivamente a massa dos encargos sujeitos a juro e amortização. Da essencia dessa especie de contractos é, pois, aggravarem a afflicção aos povos arruịnados, que a elles se aventuram. Não podem ser negocio sincero e honesto nem da parte do devedor, nem da do credor. Um conta apenas ganhar tempo, entregando o resto á fortuna. O outro simula beneficiar, para dominar mais completamente o fallido. Por isso não se conhece um só caso dessa especulação insidiosa, em que ella não sossobrasse». (I)

Se não estivessemos apenas registrando tão notavel opinião, procurariamos contestal-a inquirindo primeiramente:-qual é, na generalidade dos casos, o contracto de divida que deixa margem ao devedor honesto, porém, impontual ou remisso e que, antes de tudo, não cuida de ordenar as suas finanças?

Uma opinião, justamente considerada e que levantou-se logo contra o convenio, exculpando especialmente a fórma assás reservada pela qual era negociado, foi a do snr. senador Leite e Oiticica. Sua excia., reservando o direito de analysal-o, após a sua publicação do contracto, em vibrante discurso, pronunciado na sessão do senado de 18 de Julho deste anno, manifestou-se ainda francamente contra tudo quanto se fez.

(i) Imprensa de 26 de Junho de 1899 . Respondendo á esta apreciação escreveu o dr. Ferreira de Araujo, em editorial da Guzeta de Noticias do dia immediato, o seguinte:- «Esse emprestimo, essa capitalisação de juros e amortisação durante um certo tempo, não importa inevitavelmente uma aggravação de encargos, porque a folga que elle concede ao devedor fornece a este o meio de libertar-se pelo menos em parte do mal que sobre a sua solvabilidade exerce um de seus elementos de ruina o cambio. Durante esta folga a melhora do cambio, o augmento da producção, os novos impostos, a economia severa, a fiscalisação das rendas e todos os melhoramentos administrativos de ordem economica e financeira com que póde occupar-se o governo, que deixa de ter por algum tempo a faca aos peitos, podem mudar radicalmente a situação...» 
«O governo, disse sua excia., agachado no seu mutismo, na sua inercia, deixa que se consumme a queda do nosso credito, muito contente com a proposta que meia duzia de interessados lhe fizeram acceitar como unica alternativa possivel para a bancarrota completa, premio de sua incapacidade!» (I)

$\mathrm{Na}$ imprensa coube á Tribuna combater o convenio em diversos artigos que brilhantemente concorreram para o inteiro esclarecimento da questão (2); tambem o Paiz oppoz-se ao convenio declarando, em editorial de 29 de Junho de i 898 - «que delle hão de dizer os economistas e financeiros o que disseram do emprestimo Morgan, nem mais nem menos. 》

7).-Apreciações favoraveis ao convento. Um dos estadistas brazileiros que primeiro se manifestou pelo convenio, foi o snr. senador Rodrigues Alves que, varias vezes, tem occupado a pasta da fazenda.

Em sessão do senado de 18 de Julho de 1898 , pronunciou s. excia. notabilissimo discurso do qual extractamos o seguinte trecho. $-\ll \mathrm{O}$ senado conhece a situação do paiz, e não é necessario que eu repita as peripecias dessa phase tristissima que temos atravessado: a receita dando mal para o encargo das despezas e o deficit sempre crescente, sempre ameaçador. Quando a situação era de tal sorte grave o que fez o Congresso? mandou ao Governo um orçamento desiquilibrado, orçando a receita da Republica em 342 mil contos e decretando despezas no valor de 372 mil contos, isto é, creou desde logo uma differença de

(1) O snr. Senador Oiticica analysou a carta que os snrs. Rothschild \& Sons dirigiram ao $d r$. Campos Salles e a resposta deste a quai, na opinião insuspeita do Times de 20 de Júnho de 1898 , foi correcta e satisfactoria. Esta correspondencia encontra-se no «Retrospecto Commercial» do Jornal do Commercio de I3 de Julho de I898 e de 3I de Janeiro de I 899 .

(2) Vide a Tribuna de Junbo e Julbo de 1898. 
30.000 contos em desfavor da receita comparada com a despeza. Contava, é certo, o Congresso com o beneficio das novas tarifas das Alfandegas, mas este calculo falhou porque a renda diminuio. Fez-se o calculo da despeza contando-se com a taxa cambial de 8, mas esta desceu quasi a 5 ; e para cumulo de nossa infelicidade, quando o cambio cahio determinando um deficit maior, por um conjuncto de causas surgio a crise do café, diminuindo consideravelmente o preço desse producto, aggravando ainda mais as condições do mercado de cambio. No meio destas difficuldades o Governo procurava recursos por toda parte; o seu credito no paiz póde-se dizer tinha desfallecido, não havia dinheiro; lá fóra os capitalistas extrangeiros não queriam trazer os seus capitaes para um paiz que se achava em condições economicas e financeiras tão difficeis. Em julho havia grande pagamento a fazerse de oitocentas e um milhão de libras esterlinas; era a quantia necessaria para pagamento de juros.» (I)

Assim expondo a situação, inquiria: Qual o expediente que restava ao Governo senão celebrar o convenio? Qual outro caminho ou plano a seguir para conjurar tamanhas difficuldades?

Outra opinião emittida, a favor do convenio, foi a do illustre snr. dr. Serzedello Corrêa, ex-ministro da fazenda, que a respeito assim exprimiu-se, na Camara dos Deputados, em sessão de I 3 de Setembro de i 898:- «Em synthese o convenio é a substituição dos pagamentos em especie pelo pagamento em novos titulos de renda - elle é pois um emprestimo celebrado, porém, ao par, exclusivamente destinado ao serviço da nossa divida...»

Ainda ha pouco, em sessão de 9 de Setembro ultimo, accrescentou s. excia.:- « O accordo de Lon-

(1) Este discurso está publicado no Jornal do Commercio de 19 de Julho de 1898 . 
dres foi apenas um interregno para nos apparelharmos afim de ou dominar as urgencias da situação ou nos entregarmos perdidos, desmoralisados e sem credito aos horrores de uma situação em que não quer pensar, mas que podia ser identica a do Egypto ou da Turquia.»

Diversos orgãos da imprensa nacional e extrangeira se declararam favoraveis ao convenio.

No conceito do Fornal do Commercio (I) «foi elle, effectivamente, de incontestavel vantagem para as nossas finanças e ha de concorrer para o melhoramento das condições do paiz». Para a Gazeta de Noticias cujo redactor chefe sustentou larga polemica em favor do convenio (2) foi elle «o ponto em que levou uma série de erros accumulados e só um erro poderiamos commetter ainda e seria não empregar todo o nosso esforço em honrar o compromisso que por elle assumimos.» (3)

Entre muitas folhas extrangeiras que se occuparam do assumpto, o Times, de 16 de Junho de 1898 , declarou: «E' fóra de duvida que o presente projecto não beneficiará permanentemente o Brazil se o Governo brasileiro, durante os proximos tres annos, não só não introduzir como não levar a effeito outras medidas de alta economia e administração no paiz. O Bullionist, depois de expor as condições do convenio, assim concluiu um extenso artigo:- «Desde que se iniciou o funding os titulos do emprestimo de i 889 subiram de 4 I a $66 \frac{1}{4}$, os dos caminhos de ferro de Minas

(I) Editorial de 19 de Novembro de 1898 . Vide tambem o Jornal de 27 de Julho de 1898 . Identica opinião tiveram a Noticia e o Debate de Junho e Julho tambem de 1898 .

(2) Editoriaes dos mezes de Junbo e Julbo de 1899

(3) A integra deste artigo encontra-se na Brasilian Revieze de 23 de Junho ultimo. Esta folha, em I5 do mesmo mez e anno, consagrou um lisonjeiro artigo sob a epigraphe o "Anniversario do Funding.» 
de 43 a $69 \frac{1}{2}$, as novas apolices são hoje cotadas a 9r. Como se vê a situação geral das finanças brazileiras inspira confiança e esperança». Edmond Théry, redactor chefe do Économiste Européen, além de emittir identica opinião, tratou especialmente em um folheto (I) do convenio, mostrando as vantagens dessa operação tanto para as finanças federaes, como para os credores do Brazil.

Iriamos longe se fossemos aqui consignar todas opiniơes dos demais organs autorisados que, em sentido favoravel, se pronunciaram acerca do convenio.

8).-Dados estatisticos. Pelo convenio ficaram suspensas, por I 3 annos, a amortisação da divida externa e interna de i 879, para cujo serviço o governo despendia annualmente, $£ 545.730$. (2)

Os juros da divida e as garantias de juros pagos, annualmente, na importancia de $£ 2.877 .53$ I passaram a ser realizados em titulos emittidos ao par, juros de $5 \%$, e resgataveis em 63 annos a $1 / 2 \%$ ao anno de i9I I em diante.

Durante o triennio que decorrer de $\mathrm{I} .{ }^{\circ}$ de Julho de 1898 a 3 de Julho de I90 I, a emissão de titulos do funding será na importancia approximada de $£ 8.604 .760$, somma essa em que justamente importa o serviço dos juros dos emprestimos de I879, I883, I 889, I 895, d'Oeste e das garantias de juros das Estradas de Ferro e á qual quantia corresponderá um resgate de papel moeda de I I 5.300:000\$000. (3)

(1) Les Fiñances et le change du Brésil, pag. 79 á 87 .

(2) A amortisação dos emprestimos internos até hoje não tem sido levada a effeito, em virtude da lei n. 91, de 23 de Outubro de 1839 e n. I58, de 18 de Setembro de 1840 .

(3) Até 30 de Setembro haviam sido reggatados 52.190:053\$000. Diario Official de 2 de Novembro de 1899. 
N'esse momento (I) as responsabilidades totaes do Thezouro, com os serviços ora incluidos no funding e com o do proprio funding, serão os seguintes:

Emprestimo de 1879 interno

I 23.440

\begin{tabular}{|c|c|c|c|}
\hline$\Rightarrow$ & $\gg$ & I 889 & externo \\
\hline & » & I 895 & $»$ \\
\hline & » & I 888 & » \\
\hline & $»$ & I 883 & $\gg$ \\
\hline & 》 & Oeste & $\gg$ \\
\hline & & Fundu & \\
\hline
\end{tabular}

735.528

366.580

238.436

I 48.140

I 69.404

$\frac{430.238}{2.211 .766}$

Garant. de E. de F.

I.I I I. 282

$£$.

3.323 .048

A arrecaḍação de I $5 \%$ ouro, será a seguinte na proporção das arrecadações aduaneiras:-para I 80 mil contos $£$ 3.000.000; para 200 mil $\& 3.333 .300$ o que habilitará o paiz a recomeçar o regimen normal dos pagamentos.

A nossa divida externa que era de $£ 37.697 .900$ em I 898, passará a ser de 45.000.000 em I90 I.

$\mathrm{Na}$ peior das hypotheses, findo o convenio, voltar-se-á ás mesmas difficuldades de i 898, (visto estarem adiadas as amortizaçōes) sendo preciso quasi igual quantidade de ouro para o serviço das nossas responsabilidades externas.

9).-Confronto com o convento Argentino. E' innegavel que ha differenças radicaes entre o novo arranjo e o arreglo argentino o qual contém effectivamente clausulas assáz onerosas, como passamos a indicar:

(I) A Noticia de 4 de Julbo de 1899, publicou um detalbado artigo sobre a execução do funding, exhibindo dados estatisticos completos. Estes foram transcriptos na Gazeta de Noticirs, de 5 d'aquelle mez e no Jornal do Commercio, de 6 tambem do mesmo mez. O snr. senador Rodrigues Alves em seu discurso no senado, na sessão de 18 de Julho de 1898 , logo após o convenio, exhibio os mesmos dados com insignificante differença. 


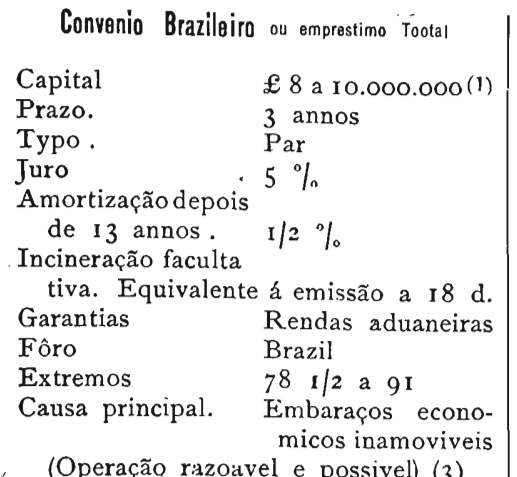

Convenio Argentino ou emprestimo Morgan (2)

$\begin{array}{ll}\text { Capital } & £ \text { I } 5.000 .000 \\ \text { Prazo. } & 3 \text { annos } \\ \text { Typo. } & \text { Par } \\ \text { Juro } & 6 \% \\ \text { Amortização, desde } & \\ \quad \text { logo } & \text { I } \% \\ \text { Incineração obriga- } & \\ \quad \text { toria } & \text { I } 5 \text { milhões } \\ \text { Garantias } & \text { Rendas aduaneiras } \\ \text { Fôro } & \text { Um tribunal com } \\ \text { Extremos } & \text { séde em Londres } \\ \text { Causa principal. } & \text { Abuso do credito } \\ \text { (Operação insupportavel, inexequivel) (4) }\end{array}$

\section{Basta a simples inspecção sobre estas notas para} se reconhecer quão injusto é equiparar as duas operações, primeiras no genero, realisadas na America.

(I) A commissão do orçamento actual calculou a emissão do emprestimo em $£ 8.604 .660$ correspondente a um resgate de $115.300: 000 \$ 000$.

(2) O convenio argentino foi entabolado pelo governo de Pelligrini A somma total dos compromissos em ouro da Republica attingia entâo a $£$ 37.463.383; ao iniciar a revisão de $1893 £ 44.152 .980$, em 31 de Dezembro de 1898 a $\& 63.279 .555$, conservando hoje o serviço da divida 38 a $39 \%$ da receita, ou quasi igual proporção á França e só inferior á Italia cuja divida absorve $50 \%$ da receita. As principaes autoridades em materia de finança, se pronunciaram contra:-o ministro Terry considerou o convenio "caro e humilhante»-Relat. das Fin. tomo r. ${ }^{a}$ pag. I56; o snr. Agostinho de Vedia declarou pela Tribuna, de 22 de Abril de 1893: "Esta negociação não se explica senão por uma allucinação da nossa parte»; o sur. A. Martinez consideruu a peior negociação que se podia realisar ou antes uma desastrosa operação, "Les Finances de la Republiquè Argentine», pags. 253 e 256.

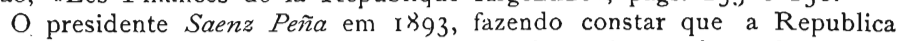
não podia supportar a continuação do convenio denunciou-o, chegando a novo accordo firmado pelo ministro Romero e vas seguintes bases:--Para os primeiros 5 annos ( 12 de Julbo de 1893 a 12 de Julho de 1898 ) pagamento dos juros sómente na razão de $31 / 2 \%$, obtendo pois uma importante reducção na metade do serviço annual!, d'ahi até i 2 de Julbo de Igor serviço completo de juros e commissão; de 12 de Julbo de I9or em diante, juros, commissão e amortisação. Accordo que ainda está vig(srando.

Consulte-se a respeito:-O Estado de $S$. Paulo de 23 de Março de I 898, o Panz de 29 de Maio de 1898 , o Jornal do Commercio de 30 do mesmo mez e anno, $A$ Tribuna de 6 e 7 de Junho do mesmo anno, a Imprensa de 23 de Junbo e o Brazilian Reviez de 4 de Julbo ambos do corrente anno.

(3) Esta apreciação encontra fundamento no extenso artigo sobre o activo nacional e que, sob o titulo de "Ainda é tempo", publicou o $d r$. Pires de Almeida no Jornal do Commercio de 19 de Março de 1899 e.. na execução do convenio.

(4) . Como os factos demonstraram. 


\section{EXECUÇÃO DO CONVENIO}

10).-Convencidos de que o convenio brazileiro, de 15 de Julho de I898, foi uma operação rasoavel, determinada pelas condições do momento e da qual resultou incontestavel repouso economico de alta valia para o paiz-nada mais resta do que fazermos votos pela sua fiel observancia e completa execução.

Durante o actual interregno já o governo tem levado a effeito algumas medidas tendentes á reconstituição financeira e estamos certos continuará iniciando e realizando outras que forem indicadas pelos grandes interesses nacionaes.

Verdade é, portanto, que vae sendo rigorosamente cumprido, nenhuma conveniencia ha em denuncial-o (como aliás já foi suggerido) para não encontrarmonos em identica situação a que chegou a activa e emprehendedora nação argentina.

Ali, a despeito de todo mundo reconhecer que a denuncia do convenio de I89 I foi um acto justo e patriotico, de indeclinavel necessidade-todavia não deixou tal resolução de prejudicar os creditos do paiz, tendo até contribuido para o insuccesso de um emprestimo ultimamente pretendido nos mercados monetarios da Europa.

$\mathrm{Na}$ cidade de Antuerpia (I) quando constou aos credores que o Governo Argentino procurava negociar um emprestimo no começo do anno, entraram elles na bolsa e levaram-na a decidir que nenhum novo emprestimo argentino teria cotação emquanto todos os credores não estivessem satisfeitos. As bolsas de Bruxellas, Pariz, Londres e Berlim negaram-se a dar um passo tão decisivo, mas deixaram que livremente se inferisse que

(1) Brasilan Review de 4 de Julho de 1899. 
embora não houvesse recusa antecipada de cotação ellas se reservavam para estudar o assumpto, quando lhes fosse requerida a cotação.

Mas, em relação ao actual convenio, será possivel que, no curto espaço de tempo de tres annos, estejam regularisadas as finanças do Brazil?

Examinaremos, mais adiante, esta questão. (n. IV)

11). - Effeiros do convenio. Os principaes effeitos do convenio foram os seguintes:

a) - affastar o governo do mercado de cambiaes. Tal era a perniciosa influencia que semelhante facto produzia no mercado monetario que impossivel tornou-se, afinal, o calculo orçamentario para as differenças do cambio.

Esta verba teve o seguinte movimento:

$\begin{array}{lr}\text { I } 895 . & 29 \cdot 550: 400 \$ 000 \\ \text { I } 896 & 45.000: 000 \$ 000 \\ \text { I } 897 & 55.000: 000 \$ 000 \\ \text { I } 898 & \text { I I } 0.000: 000 \$ 000\end{array}$

b) - a conversão do emprestimo interno (ouro) de I 890 em papel, bem como os juros pagaveis tambem em ouro.

Esta operação foi realisada em virtude do dec. 2907 de I I de Junho de I 898, sendo convertidas (I) as apolices $4 \%$ ouro, em titulos de $5 \%$ papel, e todos na importancia de I 24.655:000\$0oo, obtendo só nesta operação, ha tanto tempo reclamada, uma economia superior a vinte mil contos.

(I) Esta conversão, se bem que realisada quatro dias antes do convenio, foi todavia subordinada ao plano financeiro que o governo tinha em vista. 
$\mathrm{E}$ as providencias tomadas em relação aos emprestimos de r 868 e i 889 , sendo que os juros deste não pezam mais no orçamento e os titulos daquelle foram submettidos a um regimen semelhante ao funding pelo qual a despeza com os respectivos juros ficou diminuida de I.500:000\$000. (I)

c)-a creação de um fundo de resgate e outro de garantia do papel moeda (2) cujo exito a ninguem é dado avaliar, com segurança, por serem medidas de ordem artificial, sem effeito permanente e duradoiro, principalmente attendendo-se á depressão economica do paiz.

Sem resolver-se o problema da producção, sem o concurso simultaneo dos elementos economicos, de lenta elaboração mas de resultados decisivos, nada se conseguirá, de estavel e de definitivo, em prol das finanças nacionaes, embora se estanque a emissão e se garanta o almejado equilibrio orçamentario. (3)

(I) A circulação destes titulos, juros ouro, era em 3 I de Março ultimo a seguinte: emissão de 1868 a $6 \%$ de Ir.584:590\$; emissão de 1879 a $4 \mathrm{I} / 2 \%$ de 22.035:500\$; emissão de 1889 a $4 \%$ de $18.350: 000 \$$. Relat. da Fazenda de 1899, pag. 14.

-Consulte-se o parecer n. 144-I899. Diario do Congresso, pag. I3 I5. A lei n. 640 de I4 de Novembro de 1899 que orçou a receita geral da Republica para o exercicio de 1900 no art. $2 .^{\circ} \S 4 .^{\circ}$ autorisou o Governo a effectuar operações de credito para o resgate dos emprestimos de I868 a 1889 .

(2) Esta ideia indicada na Mensagem lida no Congresso Nacional, em 3 de Maio deste anno; pelo $d r$. Campos Salles, foi incluida no projecto do deputado Augusto Montenegro, por elle fundamentada em sessão de 26 de Junho e convertida em lei n. $58 \mathrm{r}$, de 20 de Julho ultimo. Ficou assim constituido um fundo especial appliçavel ao resgate do papel, com os seguintes recursos:-renda (papel) proveniente dos arrendamentos das estradas de ferro - cobrança da divida activa-rendas eventuaes e saldos-; para garantia uma quota de $5 \%$, ouro, além dos $10 \%$ sobre os direitos de importação;--saldo de certas taxas em ouro-renda (ouro) proveniente de arrendamento das Estradas de Ferro-rendas eventuaes, ouro.

-O art. 4 da cit. lei, é assim expresso: - O fundo de garantia será constituido em metal ou seu equivalente, depositado em um estabelecimento bancario de Londres, devendo os juros do deposito ser encorporados ao mesmo fundo.

(3) Os fundos do resgate e de garantia do papel moeda são, todavia, pontos capitaes do programma do governo; acerca do primeiro assim referiu-se o dr. J. Murtinho, em seu relatorio, pag. XXXII:- "O enthusiasmo que 
d) -as differentes e proveitosas medidas como a economia real (I) em diversos departamentos da administração-a creação dos impostos internos (2)- - e o estabelecimento do imposto em ouro o qual virá evitar os grandes abalos ou a trepidação no movimento commercial occasionada pela concorrencia do Governo ao mercado de cambiaes.

«Estes tres agentes financeiros:-a reducção da despeza, em todos os ramos da administração publica, para corresponder ao empobrecimento actual do paiz; -o imposto de consumo para corresponder á nossa viciosa organisação industrial-e o imposto em ouro para corresponder ao mercado de cambio, em que uma massa enorme de papel moeda desvalorisado imprime o cunho de uma sensibilidade doentia, constituem, na expressão do governo, os tres apparelhos de

tenho pelo resgate do papel-moeda não me céga, porém, a ponto de não ver os perigos que elle póde trazer se não fôr executado com grande prudencia e extraordinario criterio. O perigo está em que a reducção do papel traz como consequencia uma reducção na amplitude da circulação, na extensão do apparelho circulatorio, que se manifesta por grande diminuição de negocios. Dahi uma modificação profunda na estructura da sociedade, considerada debaixo do ponto de vista industrial, commercial e governamental». Mais adiante accrescenta o mesmo Ministro:- «E' necessario mesmo algumas vezes suspender temporariamente a acção do resgate. . ".

- Como se vê, é mesmo uma medida difficil e complexa; um remedio perigoso! E' pena que o illustre ministro que tão bem sabe curar a fraqueza dos doentes pelo emprego de tonificantes não applique a sua therapeutica á anemia economica do paiz, tomando o desenvolvimento das forças productoras como o ponto de partida de todos seus planos de governo!

-O snr. senador Leite e Oiticica, em discurso pronunciado no senado, em sessão de I5 de Julho de 1899 , demonstrou que a ideia de fundos de resgate e garantia não é.nova, visto ter sido, por vezes, suggerida no Congresso desde i 89I. (Diario do Congresso Nacional, pag. 73I).

(1) A «Noticia», em I6 de Novembro ultimo, consagrou suggestivo editorial ao primeiro anniversario do actual governo e por onde se vê que o convenio kabilitou o governo a pagar 47.000 contos da administração transacta; resgatar 52.000 (papel moeda); remetter para Londres 26 mil; ter em caixa egual quantia.

(2) Na Argentina a creação dos impostos internos de consumo fez parte do plano financeiro de Peligrini cujo governo realisou o primeiro convenio. José A. Terry «Finanzas»-Conferencias, pag. 63.-Alberto Martinez «Les Finances de la Republique Argentine», pag. 269. 
adaptação do nosso organismo financeiro ao nosso meio economico.» (I)

e)-a refórma radical na confecção da lei de meios, como se deprehende da simples inspecção de sua nova structura, para o anno de 1900 .

Assim é que creou um titulo especial de receita oriunda da emissão annual do emprestimo de que o orçamento cogita, no valor de $25.627: 876 \$ 593$ para occorrer á despezas inscriptas no orçamento da Fazenda, que montam a I 5.745:251\$278 e outras do orçamento da viação. Por outro lado, em virtude do mesmo convenio, vê-se no orçamento vindouro a quantia de 44.869:379\$000 (papel) destinada á incineração, alvitre adoptado, o anno passado, pelo Congresso Nacional, quando teve de resolver sobre o destino a dar ao deposito constituido pelo citado convenio. (2)

Além destes effeitos do convenio financeiro podiamos indicar outros principaes como a incineração do papel moeda que faz objecto do seguinte $\S$.

12). - InefFicacia da inCiNeração do yapel MOEJja. Uma das clausulas do convenio é o deposito, durante o periodo de tres annos, do equivalente dos titulos emittidos em papel moeda, ao cambio de $18 \mathrm{~d}$.

O destino desse deposito é assin expressamente designado:- «O papel moeda depositado ou será retirado da circulação e destruido ou se quando o cambio tornar-se favoravel, será applicado na compra de lettras em Londres, a favor dos snrs. N. M. Rothschild \& Sons, afim de ser levado ao credito do Fund para

(I) Relatorio da Fazenda de 1899 , pag. XXXVIII.

(2) Vide o parecer n. I44-1899, da Commissão do Orçamento.--Id. Lei n. 559 de $3 \mathbf{I}$ de Dezembro de r 898 , art. $7 .^{\circ}$ e n. 35 do art. 43 da lei n. 652 de 23 de Novembro de 1899 que fixou a despesa para 1900. 
o futuro pagamento em ouro dos emprestimos e garantias das Estradas de Ferro».

O Governo em vez de, immediatamente, indicar destino mais conveniente a cerca de I I 5 mil contos que depositará dentro daquelle periodo-preferio o processo da incineração e, de accordo com a lei orçamentaria de I898, já inutilisou até 30 de Setembro ultimo 52.1 90:053\$00o. (I)

Aquella clausula do convenio oriunda da crença (principalmente no extrangeiro) de existir superabundancia de papel moeda em nosso paiz-com verdade, não tem produzido o desejado effeito. Seu intuito era a melhoria do cambio e a cotação d'este ainda não excedeu de $815 / 16$ d. sobre Londres, após o convenio, estando presentemente a menos de $7 \mathrm{~d}$.

E' geral a opinião contraria á incineração feita sem saldos orçamentarios.

O snr. Ruy Barbosa combateu vigorosamente a incineração do papel moeda. (2) Escreveu aquelle publicista:- «Mas estar em deficit, ser obrigado para lhe acudir, a carregar no peso dos tributos, não ter certesa ainda assim de vencel-o, e desviar de seu destino inviolavel, a solução das dividas instantes esse peculio extorquido á nação em nome de suas despezas necessarias, para o incendiar é aventurar-se a um arbitrio, sobre contrario ao bom senso, inconciliavel com a moral e com a humanidade. »

A opinião mais corrente no paiz é contra a incineração, a despeito de julgarem alguns que esse mal póde ser remediado com uma correspondente emissão.

(I) Diario Official de 2 de Novembro de 1899, pag. 9III; Jornal do Commercio de 23 de Outubro ultimo.

(2) Vide os artigos sobre esta questão na Imprensa de 16 e I 8 de Junho e de 20 e 23 de Julho de 1899 . 
O snr. conselheiro Angelo do Amaral, manifestando-se a respeito, (I) accrescentou:-O resgate, além de inopportuno, é perigoso. Ou toda emissão está effectivamente em gyro ou grande parte della jaz inactiva nas caixas dos bancos e em poder dos particulares. Na primeira hypothese a incineração ha de produzir uma revolução nos preços, mas em sentido contrario a que foi produzida pelas emissões posteriores de I889, isto é, aggravará a crise economica, devida principalmente á desvalorisação do nosso primeiro artigo de exportação, difficultará mais os descontos e precipitará o paiz em uma situação peior do que a que se trata de remediar. $\mathrm{Na}$ segunda hypothese, a incineração será um sacrificio inutil emquanto se restringir á quantidade de papel que está fóra da circulação, porque igual quantidade virá substituil-a.

O snr. conselheiro Lourenço de Albuquerque, condemnando cathegoricamente a incineração, assim esclareceu ainda a questão:-Diz-se: nada mais facil do que uma emissão se for necessario; logo se a queima for um mal terá prompto remedio. Erram os que assim discorrem, e provêm o seu erro de não considerarem que os damnos de uma emissão, mesmo de pouco vulto que faça o governo depois da moratoria, serão incomparavelmente aos beneficios que possa ter produzido a queima de muitos milhares de contos de réis. Será o despertar da desconfiança com todos seus funestos corollarios: terá a gravidade de uma recahida. »

$\mathrm{Na}$ Republica Argentina o governo tambem assumiu formal compromisso de retirar da circulação I 5 milhões de piastras, durante os tres annos do convenio, e posto tivesse estabelecido um imposto especial para

(I) Jornal do Commercio de 9 de Julho e de 2 de Agosto de 1899. 
esse fim, não chegou a incinerar mais do que 4.834 .287 nos annos de i89i e I 892 e de 8.865.816 em r 893 e I 894.

Apreciando a inefficacia deste expediente, escreveu o snr. Alberto Martinez:- «Comme je l'ai dejà avancé, les résultats pratiques de cette mesure, dans le sens de la valorisation de la monnaie dépréciée, furent nuls: le pouvoir executif brûlait, religieusement e avec une grave solemnité, le i 5 de chaque mois, une somme déterminée-en general, 500.000 piastres de papier monnaie--mais il resultait que la valeur de celui, ci, loin d'augmenter, diminuait encore davantage, au tableau des cotes journalières de la bourse». (I)

Reconhecendo o mallogro cla incineração o governo, pelo orgam do seu ministro das finanças, declarou :- «o poder executivo reconhece que 8 milhões de piastras retiradas annualmente da circulação não póde ser uma somma assáz forte, para alterar de uma maneira fundamental, o preço do nosso papel, mas o que affirma é que esta quantidade será efficaz, uma vez augmente a producção do paiz, que a exportação exceda a importação, isto é, que os saldos internacionaes sejam favoraveis à republica.» (2)

Verificou-se, pois, que tudo dependia do desenvolvimento da producção, sob todos os seus variados ramos, e que a incineração não podia dar resultado sem o excedente progressivo ou ao menos constante, nas receitas do Estado. (3)

(I) «Les Finances de la République Argentine», pag. 545 .

(2) "Memorial das Finanças e da Administração Nacional», I893.

(3) Léon Say, em seu "Dictionaire des Finances", vol. I, pag. I3or, escreveu: "Un des problèmes les plus difficiles à resoudre est le retrait du cours forcé. Tant qu'un pays soumis à ce régime se trouve, par suite d'un excés d'importation, dèbiteur de saldes considérables envers l'étranger, le retrait reste impossible. La pratique l'a demonstré dans maintes et maintes circonstances.»

$O d r$. Amaro Cavalcanti, em seu livro «O Meio Circulante Nacio. nal.» pag. 298 e de seus «Elementos de Finanças » pag. 430 affirma:-—Não 
13).-QUeSTÃo DE PRINCIPIOS. As principaes medidas que o governo está levando a effeito para a inteira execução do convenio, para obter a valorisação do meio circulante e voltar aos pagamentos em especie, são pois as seguintes:-retirada gradual do papelmoeda-creação dos fundos de resgate e de garantia —reducção das despezas-impostos internos -imposto em ouro.

Todas estas medidas, de ordem artificial, são subordinadas ao pensamento do actual presidente da Republica, e assim expresso na Mensagem de 3 de Maio ultimo:- «Estou convencido de que a solução da questão financeira depende menos das forças naturaies do paiz do que do acerto das medidas que o poder publico tiver de adoptar.»

$\mathrm{O}$ actual ministro da fazenda cuja orientação se filia á escola liberal e individualista, com a mesma uniformidade de principios em relação á questão do meio circulante, assim definiu-se:- -A solução pelo augmento do valor da exportação, a que mais conviria aos interesses do paiz, porque traria a valorisação da circulação sem diminuir-lhe a extensão é extremamente lenta para um problema tão urgente, mas póde e deve servir de auxiliar e complementar á solução pela reducção do papel pelo meio circulante». (r)

«O effeito da reducção da massa de papel sobre a elevação da taxa cambial e consequente valorisação

é queimando parte do papel-moeda, todo elle mesmo se quizerem, que a circulação ha de tornar-se metallica. E' condição preliminar do resultado dessa operação que haja excedente progressivo ou ao menos coustante nas receitas do Estado....».

(I) O Jornal do Commercio de I de Outubro de I899, criticando o relatorio do actual ministro da Fazenda, destacou entre as suas conclusões a seguinte: — «Só uma reduç̧ão na massa do papel ou um augmento no valor da exportação poderá elevar a taxa cambial normal; e como este augmento é de um -processo lento e duvidoso, elle crê que deve perseverar em queimar o papel.» Achar uma lej rigorosa entre a circulação existente e a parte da produç̧ão que 
de nossa circulação monetaria é, pois, um facto incontestavel.

Esse effeito, pequeno a principio, em virtude da exiguidade da quantia retirada da circulação, ir-se-ha accentuando com o augmento do resgate, e estou convencido de que com o mesmo valor de 24,5 milhões esterlinos para nossa exportação, e independentemente de qualquer entrada de ouro do exterior, não havendo causas deprimentes de ordem politica, o cambio subirá a 9, IO, I 2 e I 5 quando tivermos redusido a circulação a 650, 580, 490, 390 mil contos.» (I)

Synthetisando as ideias contidas nos trechos acima transcriptos que se prestam á extensa analyse, chegaremos ás seguintes conclusões :

r. - - que é secundaria a questão da expansão das forças economicas do paiz, como aliás attesta o facto de não ter-se ainda resolvido nenhum problema agricola;

$2 .^{\circ}$-que por ser extremamente lenta tal evolução deve ella ser deixada á lucta da concorrencia.

Em relação á ordem economica do paiz ou a seu principal ramo de producção, preconisa s. excia.«a lucta da concorrencia entre os diversos lavradores produzindo, por meio de liquidações, a selecção natural, manifestada pelo desapparecimento dos inferiores e permanencia dos superiores.»

$3 .^{\circ}$-que dependendo a reorganisação financeira da valorisação do meio circulante-á retirada gradual do

é exportada, quasi que toca os limites do absurdo, accrescentou o Jornal. $-\mathrm{Na}$ mesma folha, em 6 do mesmo mez, appareceu um artigo, attribuido ao ministro da Fazenda, em que explicou-se a fórmula apresentada, não duvidando que uma lei sobre o valor do papel-moeda expresso mathematicamente é uma cousa impossivel no estado actual dos nossos conhecimentos.

-O dr. Alexandre Góes, em diversos artigos publicados no Estado de S. Paulo de 3 de Outubro, criticou o referido relatorio, occupando especialmente deste interessante ponto que foi muito discutido em todos os centros commerciaes e financeiros.

(i) Relatorio do ministerio da Fazenda de 1899, pag. XXXII. 
papel corresponderá, em breve tempo, a elevação da taxa cambial.

Positivamente não cremos no exito do plano economico financeiro posto em pratica de par com a leal execução do convenio e praza aos céos estejamos errados ou se confundam as nossas apprehensões com «os gritos da ignorancia», como tão incisivamente se exprime no seu relatorio, o actual ministro da fazenda. (I)

Limitadas de um modo formal e definitivo as emissões, iniciado o regimen da dieta ou da economia na despeza publica, fiscalisada com todo o rigor a percepção das rendas-a attenção geral devia se concentrar, unica e exclusivamente, na agricultura que é a base de toda a prosperidade real do Brazil.

Infelizmente isso não succede.

Estamos de inteiro accordo com o ex-ministro da fazenda, dr. Bernardino de Campos que, em seu relatorio de 1897, pag. I I 2, escreveu:- - Augmentar a producção do paiz, fomentando as industrias, promovendo a polycultura de accordo com os climas e qualidade das terras, diminuindo as despezas publicas, eis em synthese, o processo mais efficaz com que se póde ter meios seguros para valorisar o meio circulante. (2)

(I) Relatorio do ministerio da Fazenda de I899, pag. XXXI.

(2) Em seu recente pamphleto ácerca da circulação monetaria, na Italia, indicando a reconstituição economica do paiz como base de toda e qualquer refórma financeira, escreveu Federico Flora:- «La riduzione della circolazzione non è però sufficiente da sola ad eliminare il corso forzoso se prima una maggiore produzione, un maggior resparmio, un notevole incremento della ricchezza nazionale non permettano di riscattare il debito externo o di dargli un equivalente, fazendo nel paese titoli stranieri. La contrazione della circolazione può affretare questo resultato, non produrlo. Il problema quincli è duplice: finanziario ed economico.»

$\mathrm{E}$ assim pensam a torrente dos economistas extrangeiros mais autorisados.

-O snr. General F. Glycerio, en sessão da Camara de 17 de Outubro ultimo, apoiando-se nas doutrinas intervencionistas, da maior extensão das aţtribuições do Estado, especialmente se tratando do Brazil, apresentou depois de fudamentar, um projecto de um emprestimo de roo.ooo contos cujo 
Desenvolver todos os ramos da producção nacional era o principal lemma do programma d'aquelle ministro que, como L. de Lavergne, tambem comprehendeu que não ha boa situação economica sem boa situação agricola.

Nada, porém, disso admittem em nosso paiz os extremados partidarios das doutrinas individualistas!

Effectivamente, na ordem economica, as principaes ideias do governo se reduzem a um systema logico, dedusido de certas premissas que não guardam relação ou dependencia alguma com a realidade dos factos.

Taes premissas embora evidentes, como lucidamente expoz o ministro da fazenda actual, não contendo uma verdade absoluta, jamais respondem ás condições do momento.

Erro gravissimo, diz-nos autoridade contemporanea (I) é pois esse de isolar completamente o phenomeno economico e consideral-o independente da sociedade onde o mesmo se realisa e se desenvolve.

$\mathrm{Na}$ ordem economica e na quadra presente, pretende-se isso, entre nós, e o principio dominante é o que se relaciona com a formula egoista da selecção natural verificada na desigualdade das condições da livre concorrencia e. cosi va il mondo.

14).- Tentativas de resgate frustradas. snr. conselheiro Ruy Barbosa já demonstrou brilhantemente «que a historia nacional da incineração do papelmoeda, evidencía com uma das paginas mais eloquentes, a incompatibilidade entre $\mathrm{o}$ deficit $\mathrm{e}$ o resgate, entre $\mathrm{o}$

producto será destinado á lavoura e a proporção que os mutuarios forem realisando as suas amortisações em notas, estas serão immediatamente incineradas. Diario do Congresso de 18 de Outubro de 1899, pag. 1.992.

(I) Ugo Rabbeno *L'Odierna crisi nella Scienza Economica, pag. 6. 


\section{desiquilibrio financeiro e a volta dos pagamentos em especie.»}

Para melhor comprehensão do asserto, em seguida, vamos resumir os principaes dados historicos, de accordo com que expendeu aquelle illustre financista patrio. (I)

-As leis de 6 de Setembro de 1835 e n. IO9, de I I de Outubro de I 837 providenciaram sobre o resgate, especialisando a primeira certas rendas;

- Em I 840 a I 84 I o resgate montou em 4.704:529\$000;

-Em I 856 o governo retirou da circulação as notas do Banco do Brazil e entregou ao Thesouro. ... I 7.500:000\$000;

-Em I 878 o dec. n. 6882 , de I6 de Abril déterminou que, no fim de cada exercicio, se recolhesse $6 \%$ da emissão;

-Em I 886 a lei n. 3.313, de 16 de Outubro autorisou o poder executivo a retirar da circulação cinco mil contos até nivelar o valor da moeda ao fixado na lei n. 6oI, de I I de Setembro de I 846 art. I. e nesse regimen chegou-se a resga$\operatorname{tar}$ 7.500:000\$000;

-Em I 889 o decreto I0.336, de 6 de Setembro, estabeleceu a incineração annual de seis mil contos, marcando o prazo de cinco annos para a extincção do pajel inconversivel;

- Em I 893, em execução ao decr. n. I 167 , de I 7 de Dezembro de 1892 , queimou-se 5.327:000\$0oo de papel moeda;
-Pouco depois dessa primeira tentativa, á vista do deficit orçamentario, a lei n. 9I, de 23 de Outubro de I 839, facultava o augmento que se realisou, do papel por uma emissão de 6.I I 2:730\$000;

- Em I 84 I vio-se o governo obrigado a emittir 4.720:555\$630;

-Mas, substituio-as pela mesma quantia em notas suas, pagando com somma equivalente em apolices;

-O mesmo decr. autorisou a emissão de 60.000:000\$000;

- Pouco depois teve que emittir o duplo para acudir aos bancos, nos apuros da praça;

- Mas o banco preposto ao resgate, retirando no primeiro anno..

7.775:000\$ooo, em papel, entregue ao Thesouro, a troco do seu equivalente em apolices, implicitamente repudiou, logo após a revolução, o seu contracto, requerendo ao governo o auxilio da lei n. 3263 , de I 8 de Julho de I875;

-A lei de 23 de Setembro de 1893 que approvou esse acto, cedendo aos embaraços do Thesouro, perante o deficit, eliminou d'aquella medida a clausula imperativa da incineração;

(I) Editorial da Imprensa de 23 de Julho de $\mathbf{1} 899$. 
-Em I895, por occasião do governo levantar o emprestimo de contos, de. accordo com o art. 7 do decr. 1976 , de 25 de Fevereiro daquelle anno resgatou $30.000 \mathrm{mil}$ contos;
-Em I 896 o decr. n. 2405, de I 6 de Dezembro, autorisou a substituição dos bonus emittida no valor de 80.000:000\$000 em notas communs. (I)

\section{historicas?}

Qual o ensinamento a tirar-se de todas estas lições

-Que o Brazil precisa menos de resgate, menos do proprio ouro do que aquillo com que se obtém uma e outra cousa--a producção abundante e variada, o desenvolvimento agricola, a prosperidade industrial!

Resgatar o papel-moeda, sem poder é remar contra maré.

\section{CONSEQUENCIAS PROVAVEIS}

15).-Convencidos da exactidão do conceito emittido por notavel escriptor contemporaneo:- - L'économiste peut prédire l'avenir s'il a eu soin d'éprouver ses conclusions et ses hypotheses au contact des faits» (2) - não achamos fóra de proposito tambem fazer algumas consideraç̃es sobre as consequencias do convenio de 15 de Junho, attentos os differentes factos a que temos nos referido n'este ligeiro estudo.

Já o snr. conselheiro Lourenço de Albuquerque escreveu: «O ajuste é exequivel e será lealmente exe-

(I) Além destas contradições, cumpre accrescentar que nenhum resultado obtiveram-as leis n. I349, de I 2 de Setembro de I 866 , $\$ 8$, e n. I 508 de 28 de Setembro de 1867 , art. 9, determinando se assignasse uma quota nas leis annuas para o resgate; - as leis n. 1764 , de 28 de Junho, art. 20 e n. 1836 de 27 de Setembro, art. 13, de 1870, applicando o saldo orçamentario ao mesmo fim;-a lei n. 2348, de 25 de Agosto de 1873 , idem quanto aos saldos e depositos;-a lei 2960, de 31 de Outubro de I879, art. 2r, idem, quanto ao imposto do fumo;-o decr. n. 255, de Io de Março de I 890 commettendo o serviço do resgate ao Banco Nacional;-o decr. I I54, de 7 de Dezembro de 1890 , art. 7, estabelecendo a tal providencia; - o decr. 24 I 2, de 28 de Dezembro de 1896;-emfim muitos outros actos legislativos... - Amaro Cavalcanti "Meio circulante Nacional», vol. 2., pag. 322. pag. 18 .

(2) Thorold Rogers «L'Interpretation Économique de l'Histoire» 
cutado; o que não cremos é que, no seu termo, em I 5 de Junho de igor, sejam taes as nossas condições que possamos voltar, com segurança, ao regimen normal dos pagamentos. Finanças avariadas, como as nossas, não se reconstituem e consolidam no curto periodo de tres annos; destruir será senipre muito mais facil que restaurar e para trazel-as ao estado em que se acham foram precisos oito annos de indefesso trabalho.» (I)

Por melhor que sejam os nossos desejos. o que ficou dito é uma previsão que nos parece segura, certa e infallivel e com a qual estamos de inteiro accordo.

Em finanças, acima do sentimento, do dever e do patriotismo, estão a fatalidade dos acontecimentos e a realidade esmagadora dos factos, com os quaes não se póde deixar de contemporisar para o exito do plano que se tem em vista.

A despeito de muitas e acertadas medidas já postas em pratica pelo actual governo do paiz que tamanho esforço tem empregado pela causa commum - não ha negar a insufficiencia do triennio para a reorganisação financeira do paiz. E' mister a renovação do prazo e as consequencias provaveis serão não só o convencimento desse facto como da inefficacia de um ou outro alvitre já tomado e exequibilidade manifesta de outras soluções a preferir.

16).--Os pagamentos em especie. Depois de referir-se á diminuição das rendas aduaneiras que espera ser compensada ou neutralisada pelo augmento certo

(r) «O programma financeiro», artigo publicado no Jornal do Commercio de 16 de Julbo de 1899. 
nos impostos internos e reducção na despeza em todos os élos da administração, eis como se exprime o illustre dr. J. Murtinho em relação a este assumpto:

«Dada, pois, com todas estas compensações e, na peior das hypotheses, uma situação semelhante a de I 898, quanto á relação entre a receita e a despeza, estaremos sem duvida, quando expirar o convenio de I 5 de Junho, em condições de voltar ao pagamento em especie, pois, como é sabido, a differença de cambio foi a causa mais notavel da suspensão d'aquelles pagamentos, e recebendo o Governo actualmente uma parte das rendas aduaneiras, ao cambio de 27 , terá incontestavelmente os recursos necessarios para o serviço no exterior sem os onus da differença de cámbio.» (I)

Infelizrnente, parece-nos, o pai\% vae ter completa desillusão relativamente a tão almejado pagamento em especie proporcionado pela arrecadação em ouro de certa parte dos impostos aduaneiros!

O novo systema, ém parte, assemelha-se ao plano já posto em pratica pelo illustre presidente do Pará na confecção do orçamento estadoal em ouro medida que difficilmente se accommoda com o nosso regimen de circulação fiduciaria.

Para chegarmos á convicção que a innovação trazida á nossa organisação financeira, não passa de mero expediente, basta inquirir:

- A não ser para conseguir-se uma regular contabilidade fiscal ou dar uma ideia exacta no conjuncto e em detalhe da despeza publica-qual a vantagem que póde advir, para a economia nacional, o facto de consignar-se no orçamento da despeza i6,387 contos, ouro, ou tres, quatro e mais vezes papel, correspon-

(I) Relatorio do Ministro da Fazenda de 1899, pag. XLI. 
dente ao mesmo ouro, para acudir-se ao serviço da divida externa?

-Exclusão feita da conveniencia do Governo receber, diuturnamente, certa quantia em ouro das Alfandegas o que realmente o dispensa de concorrer ao mercado de cambiaes - qual a vantagem que resulta, para a economia nacional, da arrecadação de 18.000 contos, ouro, de impostos aduaneiros ou tres, quatro e mais vezes papel, correspondente ao mesmo ouro?

Sob um regimen de circulação fiduciaria, absolutamente nenhuma! pura questão de fórma. mero jogo de algarismos.

O dispendio da energia, da força ou da producção nacional é sempre na mesma intensidade, num e noutro caso.

Em tal pé, pouco ou nada adianta o almejado expediente do pagamento em especie e nem com tal remedio artificial se conseguirá a reorganisação financeira do paiz. (I)

$\mathrm{Na}$ Republica Argentina chegou-se a verificar o asserto e tanto é verdade que o chefe do Estado, em notavel mensagem, foi o primeiro a affirmar:-«Le retour aux payments en métallique doit reposer sur des bases solides, pour qu'il soit durable. Il doit être dècrèté par le développement de la richesse, de la puissance industrielle et commerciale et, aussi, par la fortune accumulée et non pas en vertu d'un loi imperative». (2)

Não servio-nos, porém, esta experiencia historica!

(I) O dr. Serzedello Corrêa que tão brilhantemente tem discutido estes assumptos no Congresso Nacional, em discurso proferido em sessão de 10 de Setembro ultimo (pag. 2 I 85 do Diario do Congresso Nacional), reconheceu que o expediente dos pagamentos em especie «não basta» sendo preciso assegural-os com outras medidas.

(2) Alberto Martinez "Les Finances de la Republica Argentina pag. 532. E' tambem isso que aconselbou Arthur Raffalovick em sua con- 
17). - A novação do contracto E a unificação DA DIVIDA EXTERNA. E' opinião corrente que o exiguo e rapido prazo de trez annos não basta para o governo debellar a crise economica e financeira do paiz.

A insufficiencia desse brevissimo periodo já foi posta em evidencia pelo snr. conselheiro Lourenço de Albuquerque (I) e não fazemos mais do que assignalar aqui uma proposição exacta que aliás vae sendo confirmada pelos acontecimentos.

Quem reflectir sobre a actual situação financeira d'o paiz, tendo em vista a persistente baixa do cambio o decrescimento das rendas e outros factos-não poderá deixar de estar de pleno accordo com aquella asserção.

Importa, portanto, cuidar-se convenientemente da renovação do convenio de I 5 de Junho, exigindo-se mais vantagens embora ampliando as garantias.

Entre estas está o fazer-se extensiva a hypotheca das rendas aduaneiras a todos os titulos da divida externa.

Entre as vantagens a exigir ahi estão duas principaes:- a unificação de todos os titulos da divida externa e a reducção dos juros que são onerosos e excessivos.

A ideia da unificação já foi largamente discutida na Republica Argentina, depois que o ministro Ro-

ferencia perante a Sociedade de Economia Politica de Paris. Vide o Journal des Économistes de 15 de Setembro de 1897 ou o Économiste Français de 18 de Setembro do mesmo anno.

(1) Editoriaes do Jornal do Commercio de 16 de Julho e de 20 de Agosto' de 1899. No primeiro artigo escrevia s. excia:- «Se apezar do cumprimento religioso do accordo de 15 de Junbo e do acertado emprego dos recursos de que ainda podemos dispor, não estiver até I90 I debellada a crise financeira, não houvermos conseguido o estavel equilibrio du orçamento sem emprestimos nem emissòes, será então o caso de pedirmos aos credores que consintam na reducção dos juros dos seus capitaes, e elles não o recusarão á nossa boa fé e lealdade.» 
mero teve occasião de submettel-a á apreciação do congresso nacional, em 4 de Outubro de 189.5 , referindo-se entretanto o seu projecto aos titulos federaes e provinciaes. $O$ ensinamento de tal discussão muito póde nos aproveitar, embora seja o nosso objectivo principal uniformisar sómente o juro reduzindo-o a $4 \%$.

$E$ tal reducção é indispensavel e equitativa, inteiramente justa.

Para chegarmos á tal convicção é bastante termos, em linha de conta, os encargos referentes ás garantias de estradas de ferro, já expostos ao paiz no parlàmento nacional, pelo illustre deputado dr. Serzedello Corrêa ex-ministro da Fazenda.

- O capital das companhias de caminhos de ferro inglezes no Brazil sóbe a cerca de i 8.500.000 libras $e$, sobre esta somma, garantiu o Governo Brazileiro por espaço de 30 annos em uns casos, de $90 \mathrm{em}$ outros, juro permanente, cuja taxa varia de $6,61 / 2$ e $7 \%$ (!) ao anno e quasi que tem pago taes garantias em sua totalidade e só ahi tem uma despeza annual de mais de um milhão. (2) Casos ha de linhas ferreas em que o Governo já se acha e para muitas achar-se-á, quando cessar a garantia, no desembolso effectivo, por juros pagos de quantia superior ao dobro, ao triplo da avaliação de seu custo sem ter a posse das estradas!!.

(I) Alberto Martinez «Les Finances de la République Argentine»

(2) Diario do Congresso Nacional, pag. 2186. Discurso prounnciado em sessão de ro de Setembro de 1899. O dr. Serzedello Corrêa citou o facto da empreza ferro-via do Natal a Nova Cruz e o caminho de ferro da Bahia a São Francisco, o qual, ao expirar o prazo da concessão deve ter custado ao Governo para mais de $£^{\prime} \mathbf{I} \mathbf{1 . 0 0 0 . 0 0 0}$ por garantia de juro, ficando ainda assim a linba toda propriedade da Companbia que só terá de cedel'a ao Governo se este lhe pagar o preço fixo de $\&$ I.800.00o!

-Diante destes e outros factos que se escudam em algarismos é justo que procuremos obter dos nossos credores concessões razoaveis, tanto mais quanto uos sujeitamos a toda série de sacrificios para retomarmos os pagamentos em especie.» 
Sendo assim, ainda é tempo de se cuidar da rèforma do convenio e em, novo ajuste, o que vae mais uma vez advogar por nós, são os interesses dos proprios credores, cujos intuitos talvez não tenham outra mira senão a influencia monetaria e o predominio commercial n'este grande e futureso paiz.

18).--Reformas tributaria e monetaria. Uma vez accordado o espaçamento do prazo do convenio e estabelecidas as alterações que as circumstancias do momento aconselharem, o groverno ficará habilitado a proseguir no seu programma para chegar- «á conquista segura do supremo ideal financeiro-nunca até hoje attingido-o equilibrio orçamentario sem emissão nem emprestimo»-bella synthese, com que terminou a Mensagem de 3 de Maio de 1898 , o actual presidente da Republica, dr. Campos Salles.

Só assim o governo poderá volver suas vistas para a angustiosa situação da agricultura nacional (I) e, ao mesmo tempo, lançar as bases de duas reformas inadiaveis e urgentes, ha tanto tempo, reclamadas; - a tributaria e a monetaria (2).

(I) Em nosso Manial de Sciencia das Finanfas, procurámos demonstrar qué, sem a expansão das forças economicas do paiz, de par com uma rigorosa economia nos gastos publicos, nenhuma reforma monetaria deve ser levada a effeito, nem ao menos se poderá chegar á valorisação do meio circulante. Pags. 227 e 277 , ns. 90 e 105.

(2) O dr. Paes de Carvalho, em sua Mensagem, de 7 de Abril ultimo, ao Congresso Legislativo do Pará, disse: Retocar a constituição na parte referente á distribuição das rendas, não é uma questão para a qual a actualidade esteja a exigir uma solução urgente. O que é urgente $e$ a elaboração de uma lei confirmativa, se for caso della, e sobretudo explicativa do texto constitucional que, apezar de claro, repetidas controversias, quanto ao direito de cobranga de certas taxas, tem de algum modo obscurecido.»

$\mathrm{Na}$ Allemanha, a formula conhecida: "A' Uniãos impostos indirectos; ao Estado os impostos directos; ao Municipio os impostos locaes", foi brilhantemente comprehendida por Miguel que, por isso, conseguio invejavel renome entre as celebridades contemporaneas. Journal des E'conomistes de 15 de Outubro de 1898 . "Les Finances de la Prusse." 
- A reforma tributaria, delimitando a competencia da União, do Estado e do Municipio, impedindo a decretação e arrecadação de impostos manifestamente contrarios á linha geral traçada pela Constituição de 24 de Fevereiro de I89I, fazendo desapparecer graves e sérias divergencias, constantemente suscitadas em detrimento do vinculo federativo ou da unidade nacional.

- A reforma monetaria, tendo por objectivo o estabelecimento de um novo padrão que exprima justa relação ou equivalencia com o meio circulante, cuja posição artificial tem sido reconhecida, desde a lei de I I de Setembro de i 846 , que procurou dar ao papel moeda um valor superior ao que representava no momento! (I)

Effectivamente, no decorrer dos ultimos quarenta annos, o papel moeda só attingiu o limite fixado por tal lei, quasi que momentaneamente, em r 875 e r 889 excedendo-o em i 863 e i 864 , mantendo-se persistentemente tres, quatro e cinco dinheiros abaixo do par.

Representando a vigencia do padrão da lei de I 846 «um anachronismo injustificavel, em disparidade flagrante com a situação real da circulação» como bem exprimio-se o ex-ministro da Fazenda, dr. Bernardino de Campos (2) - é de esperar-se que semelhante reforma, aventada por $F$. Belisario em i 886, vencedora no Senado em i89i, graças aos esforços de Amaro Cavalcanti, seja em breve uma realidade.

(1) O diagramma exhibido pelo dr. José Carlos Rodrigues, á pag. I 26 de seu folheto sobre "Finanças», indica claramente semelhante facto.

(2) Relatorio do Ministerio da Fazenda relativo ao anno de 1897, pag. 129 .

-A lei n. 359, de 30 de Dezembro de r 895 e o decr. n. 226r, de 2I de Abril de I896 alteraram o padrão monetario para a arrecadação dos direitos aduaneiros. 
Essa reforma, como prenuncio do estabelecimento da circulação metallica, por sua vez jamais será duradoira e fecunda, sem a prosperidade economica e a expansão do trabalho nacional.

19).- Opiniões diversas. O snr. cons. Ruy Barbosa, comquanto não se manifestasse contra a renovação do convenio, como se infére do seu artigo, na Imprensa, de 26 de Junho ultimo, no qual aconselhou ao governo retroceder, em i 899, do que fez em i 898, como os argentinos retrocederam em i 893 do que tinham feito em 1891, melhor definio-se, quando escreveu o seguinte: «Mas antes de nos abeirarmos á raia do descredito, da hypotheca e do sequestro pela força extrangeira, antes de aceitarmos um pacto, onde se acha, resvaladio e ingreme, esse declive, antes de entregarmos á avidez ultramarina, com o privilegio executivo sobre as nossas aduanas, o orgam nutridor da existencia da União, havia um preliminar necessario, um preservativo historico, um remedio terminante por empregar e de cujo emprego nem se cogitou sequer: - a restituição dos bens nacionaes á União e o augmento de sua renda pela reforma da constituição republicana.

Além dessa não ha solução alguma. (I)»

-O snr. Paes de Carvalho, em sua ultima «Mensagem», considerando que o convenio foi um recurso que a urgencia das circunstancias nos conduzio e admittindo a possibilidade de sua revisão entende que todos os Estados devem constituir, ao lado da União, «uma só poderosa responsabilidade» prompta a manter immune o credito nacional. S. excia., lembrando uma

(r) Imprensa. Editoriaes de 26 de Junho e 7 de Julho de 1899. Mensagem apresentada ao Congresso Legislativo do Estado do Pará, em 7 de Abril de 1899 e cujos extractos se encontram no Jornal do Commercio de I6 do mesmo mez e anno. 
ideia sua, anteriormente aventada, quanto á conveniencia de se tentar uma operação no exterior, com a solidariedade de todos os Estados, além das garantias especiaes dadas pela União, assim exprimio-se: «O appello aos Estados tem todas as probabilidades de successo. Alguns delles como o de S. Paulo e Minas e outros que têm encargos de divida exterior, seriam os primeiros a preferir compromissos que visassem a restauração das finanças federaes, porque delles seriam largamente compensados pela extincção dos outros «incalculaveis e indefinidos» que thes exigem as desastrosas taxas cambiaes. Os outros, que constituem a maior parte, já fatigados de inutilisar esforços na pesquiza dos recursos monetarios, de que não podem prescindir, nos mercados extrangeiros, terião a seu turno retribuição cabal aos seus passageiros sacrificios, no melhor tratamento que os capitaes lhes dispensariam. Um só e mesmo interesse os levaria portanto, a convergirem para o alevantado objectivo de reerguer o credito do paiz.»

-O snr. dr. F. Silviano Brandão, illustre presidente de Minas, o homem da «economia» en materia de despeza publica, assignalando, em sua Mensagem de 15 de Junho de 1899 , a gravidade da situação do paiz, tambem entende que «aos Estados incumbe, como supremo empenho, no momento actual, estreitar fortemente os laços de solidariedade que os prendem á União, grande força e prestigio au pođer central afim de que se firme, de vez, a confiança na estabilidade da Republica.

-O snr. Serzedello Corrêa, reconhecendo que as medidas tomadas na vigencia do convenio não bas-

(1) O dr. Silviano Brandão é o presidente de Estado que tem conseguido maior reducção na despeza publica. $\mathrm{Na}$ vigencia de um orçamento inferior a 20.000:000\$0oo, fez reducção no valor de 5.183:806\$772. Diario Official de Minas. Supplemento ao n. I39, de I6 de Junho de 1899. 
tam para assegurar os pagamentos em especie e a prosperidade do paiz, pensa que, em momento opportuno, assim que as circumstancias o permittirem, deve o governo tentar larga operação de credito com o fim de reduzir o capital da nossa divida externa e, depois, por meio de uma ou de varias conversões successorias, fazer a reducção dos juros dessa divida e com a reducção, a unificação dos nossos titulos. Por essa forma, poderá o governo reduzir de muito o serviço da divida, obtendo assim reaes vantagens para o Thesouro. Uma vez reduzidos os nossos encargos de treze milhões a pouco mais de um milhão, estará assegurada a nossa prosperidade economica (I). Quanto á alienação da Estrada de Ferro Central, conhecendo o valor desse immovel, não será capaz de sacrifical-o em operação ordinaria e sim, usará delle com o fim de salvar o credito da Republica e dar-lhe uma base que de futuro evite os desastres de que temos sido victimas. Não é, pois, sua excia. infenso á alienação da Central (2).

- O dr. Amphilophio, em importante discurso pronunciado na Camara dos Deputados (3), estudando

(1) Discurso pronunciado na. sessão de ro de Setembro ultimo. Diario do Congresso Nacional, pag, 2186.

(2) A questão da conveniencia, alienação ou arrendamento uão está ainda bem estudada, comquanto já esteja o governo armado dos necessarios poderes para dispor desse grande patrimonio da União.

Alguns suppõem que, mesmo reduzida á metade o debito externo da União com a renda dessa Estrada, os offerecimentos de dinheiro não faltarão ao paiz cujo governo logo levantará outros emprestimos, organisando de novo este terrivel contrapeso. da nossa imprevidencia e do nosso progresso. Quanto ao arrendamento, no Jornal do Commercio de 30 de Outubro de 1897, escreveu o snr. conselheiro Lourenço de Albuquerque:mento das estradas de ferro, medida que sinceramente applaudimos embora seja a tacita confissão da incapacidade administrativa dos que governam, pode, se for feito em boas condições, dar-nos talvez um anno de respiro; não resolve, porén, ó problema financeiro: é um simples expediente. Consumidos os recursos que d'ahi se esperam, os quaes em grande parte serấo applicados ao pagamento das despezas já feitas, mais grave será a situação do to thesouro, se providencias não forem logo tomadas."

(3) Sessão de 9 de Outubro de 1899. Diario do Congresso Nacional de 10 do mesmo mez. 
a crise financeira do paiz, que julga ser devida á lesão enormissima occasionada á União, pela devolução das terras publicas, minas e proprios nacionaes aos Estados (Art. 64 da Const. Fed.), patrimonio esse de valor incalculavel que moralmente garantia os compromissos externos da Nação, lembrou o alvitre das contribuiçōes matriculares sobre os Estados Federados, como unidades subordinadas, que são, ao Governo Federal, guardada a proporção mathematica com a quota de beneficios dos valores doados.

«Esta especie de imposto, disse s. excia., em vigor nos Governos Federativos da Suissa e Allemanha e já praticada nos Estados Unidos, se nada contradiz, no seu aspecto economico, os principios da sciencia, é tambem de correcção incontestavel, no seu aspecto juridico, como acto de poder e soberania do Governo da União, attenta á dualidade organica do Governo Federal, Estado e Federação ao mesmo tempo, e, nesse duplo caracter, representando, simultaneamente e permanentemente, uma dupla associação de pessoas physicas e moraes, tão sujeitas como as outras ao imperio de sua vontade, nos limites e pela forma do seu instrumento de constituição, a constituição nacional».

- Poderiamos ainda registrar outras opiniões, enunciadas por homens competentes. relativamente ao problema financeiro do paiz, na vigencia do convenio de I 8 de Junho.

Nenhuma, porém, se nos afigura mais fecunda do que a dos congressos da lavoura, das sociedades de agricultura, de todos os centros de producção nacional, que, n'este momento, estão em agitação benefica, reclamando a attenção dos poderes publicos (I).

(I.) O Paiz de 2 I de Novembro de 1899 e Grizeta de Noticias de 23 do mesmo mez, publicaram suggestivos artigos sobre o estado da lavoura se- 
Em favor deste conceito passamos a citar o seguinte facto :

Quando em Março de r 898, na camara dos deputados de Portugal, o snr. Ressano Garcia, ministro da fazenda, defendeu, num longo e notavel discurso o seu projecto de accordo com os portadores de titulos da divida externa, levantou-se um deputado não menos illustre, o snr. Luciano Monteiro que, demorando-se por longo espaço de tempo na tribuna, não citou algarismo algum, nem de leve se referio ao numero de libras e a apolices a pagar pelo Estado aos seus credores externos. O snr. Luciano Monteiro pedio ao parlamento nacional que desviasse os olhos por instantes da triste realidade, e imaginasse o que seria o pequeno Portugal, se o governo não tivesse, a tempo cuidado sériamente da agricultura. Este orador emerito não disse nada de finanças e, sem embargo, foi o que com mais proficencia e acerto, discutio a questão financeira. Applicando o conto e usando das mesmas palavras de um apreciado jornalista (I), diremos:Só conhece a fundo a nossa crise financeira quem claramente vê como ella se relaciona com a crise da lavoura e que tanto mais depressa e mais efficazmente dominaremos a primeira quanto menos tempo consumirmos em libertar-nos da segunda.

Tambem para nós, o grande remedio da crise brazileira, de par com a indispensavel renovação do convenio, - está em, immediatamente, o Governo cuidar da producção nacional, promovendo a polycultura, amparando a lavoura de café, animando a propaganda deste producto no exterior e abrindo novos mercados

cundando o movimento agricola, considerando a agricultura como inteiramente abandonada pelos poderes puiblicos. Em S. Paulo, o jornal Lavoura e Commercio á cuja frente se acha o infatigavel batalbador $J$. A. Leite Penteado, mantém uma util propaganda em prol da lavoura.

(1) Editorial do Estado de S. Paulo de 15 de Março de 1898. 
á nossa exportação. U'ma commissão composta de homens competentes, como Luiz Barreto, Moura Brazil, Fabio Leal, André Wernek, J. Paixão e tantos outros se procedesse a um inquerito, nesta especialidade, muito auxiliaria ao Governo.

Não se comprehende como a Republica que foi buscar no Norte America, o molde de sua structura politica, não trouxesse tambem o espirito pratico daquelle povo, que, guiado por ideias proteccionistas-intelligentes, esclarecidas e não banaes e ineptaschegou ao fastigio do poder, assumindo a hegemonia da America e ameaçando dominar o mundo! (I)

\section{CONCLUSÃO}

20).--Reunindo materiaes que podem servir de base para melhores estudos sobre o convenio brazileiro, procurando no trama confuso dos factos contemporaneos, indicações geraes tendentes a modificarem a melindrosa situação do paiz, inspirando-nos em dados positivos da estatistica official e nos grandes interesses da patria, julgamos haver justificado e comprovado as seguintes conclusões:

I. $\left.{ }^{\circ}\right)$-O convenio financeiro do Brazil, realisado em 15 de Junho de 1898 , não raro julgado injustamente, foi uma operação razoavel senão salvadora, determinada pelas circumstancias e de effeitos salutares embora a inconveniente incineração do papel moeda;

2.9)-O objectivo principal do convenio--a volta dos pagamentos em especie-em nada aproveita á economia nacional, pelo contrario virá aggravar a crise

(I) O seguinte conceito de Gambetta é com prazer que sempre repetimos:-- «Fomentar, defender e proteger os interesses da grande producção nacional é a mais bella e efficaz propaganda do partido. republicano!» 
actual, á vista da insufficiencia da producção nacional e do regimen de circulação fiduciaria;

$\left.3 .^{\circ}\right)$ - - Havendo o convenio contribuido para uma certa ordem e regularidade nas finanças, torna-se indispensavel o espaçamento do prazo, nelle estipulado, afim de se levantar do abatimento em que se acham as forças naturaes do paiz, e obter-se a prosperidade economica, sem a qual será inutil toda e qualquer reforma financeira.

$\mathrm{E}$, neste momento, em que a esquadra nacional se apresta para conduzir o illustre Chefe do Estado á Republica Argentina, onde os economistas e financistas tanto estigmatizam o conceito-«El que venga atrás que arree»-fazemos votos para que dalli regresse feliz, afim de, a tempo, realisar seus planos patrioticos de governo, aliás já encetados, e, findo o quatriennio, transmitta ao successor legal, um governo forte, de renome, de reaes serviços á Republica. (I)

S. Paulo, 10 de Dezembro de 1889.

Dr. Weiga $\mathfrak{F}$ itho.

(1) Errata: Pag.: Onde está: Leia-se:

$22 \mathrm{I}$-sem que exigencia-sem exigencia.

224-do que escreveu -o que escreveu.

227-situações que -situações em que.

237-exculpando -inculpando. 